University of Nebraska - Lincoln

DigitalCommons@University of Nebraska - Lincoln

\title{
Arsenic incorporation into authigenic pyrite, Bengal Basin sediment, Bangladesh
}

Heather A. Lowers

U.S. Geological Survey, MS 973, Denver, CO, USA

George N. Breit

U.S. Geological Survey, MS 973, Denver, CO, USA

Andrea L. Foster

U.S. Geological Survey, MS 901, Menlo Park, CA, USA

John Whitney

U.S. Geological Survey, MS 980, Denver, CO, USA

James Yount

U.S. Geological Survey, MS 980, Denver, CO, USA

See next page for additional authors

Follow this and additional works at: https://digitalcommons.unl.edu/usgsstaffpub

Part of the Earth Sciences Commons

Lowers, Heather A.; Breit, George N.; Foster, Andrea L.; Whitney, John; Yount, James; Uddin, Md. Nehal; and Muneem, Ad. Atual, "Arsenic incorporation into authigenic pyrite, Bengal Basin sediment, Bangladesh" (2007). USGS Staff -- Published Research. 330.

https://digitalcommons.unl.edu/usgsstaffpub/330

This Article is brought to you for free and open access by the US Geological Survey at DigitalCommons@University of Nebraska - Lincoln. It has been accepted for inclusion in USGS Staff -- Published Research by an authorized administrator of DigitalCommons@University of Nebraska - Lincoln. 
Authors

Heather A. Lowers, George N. Breit, Andrea L. Foster, John Whitney, James Yount, Md. Nehal Uddin, and Ad. Atual Muneem 


\title{
Arsenic incorporation into authigenic pyrite, Bengal Basin sediment, Bangladesh
}

\author{
Heather A. Lowers ${ }^{\mathrm{a}, *}$, George N. Breit ${ }^{\mathrm{a}}$, Andrea L. Foster ${ }^{\mathrm{b}}$, John Whitney ${ }^{\mathrm{c}}$, \\ James Yount $^{c}$, Md. Nehal Uddin ${ }^{\mathrm{d}}$, Ad. Atual Muneem ${ }^{\mathrm{d}}$ \\ ${ }^{a}$ U.S. Geological Survey, MS 973, Denver, CO, USA \\ ${ }^{\mathrm{b}}$ U.S. Geological Survey, MS 901, Menlo Park, CA, USA \\ ${ }^{\mathrm{c}}$ U.S. Geological Survey, MS 980, Denver, CO, USA \\ d Geological Survey of Bangladesh, Segenbagicha, Dhaka, Bangladesh
}

Received 11 October 2006; accepted in revised form 22 March 2007; available online 3 April 2007

\begin{abstract}
Sediment from two deep boreholes ( $400 \mathrm{~m}$ ) approximately $90 \mathrm{~km}$ apart in southern Bangladesh was analyzed by X-ray absorption spectroscopy (XAS), total chemical analyses, chemical extractions, and electron probe microanalysis to establish the importance of authigenic pyrite as a sink for arsenic in the Bengal Basin. Authigenic framboidal and massive pyrite (median values 1500 and $3200 \mathrm{ppm}$ As, respectively), is the principal arsenic residence in sediment from both boreholes. Although pyrite is dominant, ferric oxyhydroxides and secondary iron phases contain a large fraction of the sediment-bound arsenic between approximately 20 and $100 \mathrm{~m}$, which is the depth range of wells containing the greatest amount of dissolved arsenic. The lack of pyrite in this interval is attributed to rapid sediment deposition and a low sulfur flux from riverine and atmospheric sources. The ability of deeper aquifers $(>150 \mathrm{~m})$ to produce ground water with low dissolved arsenic in southern Bangladesh reflects adequate sulfur supplies and sufficient time to redistribute the arsenic into pyrite during diagenesis.

Published by Elsevier Ltd.
\end{abstract}

\section{INTRODUCTION}

Arsenic substitution into early diagenetic pyrite and acid-volatile sulfide (AVS) is commonly proposed as a mechanism to account for removal of dissolved arsenic from pore water in marine and fresh water sediment (Farmer and Lovell, 1986; Huerta-Diaz and Morse, 1992; Sullivan and Aller, 1996; Hideki and Yoshihisa, 1997; Saunders et al., 1997; Huerta-Diaz et al., 1998; Pirrie et al., 1999; Mucci et al., 2000; Sternbeck et al., 2000; O'Day et al., 2004; Saunders et al., 2005b; Southam and Saunders, 2005; Wilkin and Ford, 2006). Arsenic assimilation into forming sulfides commonly occurs as sediment is buried below the suboxic and sulfidic redox boundary. Masuda et al. (2005) observed arsenic-bearing oxides in shallow intertidal

\footnotetext{
* Corresponding author. Fax: +1 3032363187.

E-mail address: hlowers@usgs.gov (H.A. Lowers).
}

sediment off the coast of Japan and arsenic-bearing sulfides deeper in the sediment column. Sullivan and Aller (1996) report that arsenate in shallow Amazon shelf sediments is chemically reduced during burial, released to solution and removed from pore waters with increasing depth. Similarly, Moore et al. (1988) determined that arsenic bound to iron oxyhydroxides was redistributed into sulfide in reservoir sediment on the Clark Fork River, Montana.

The arsenic contamination in south and southeast Asia is attributed to redox changes, paleogeography, and tectonic setting whereby uplifted bedrock containing arsenicrich minerals is weathered, rapidly eroded, and deposited in alluvial basins (Acharyya et al., 2000; Saunders et al., 2005a). The generally accepted model for high levels of dissolved arsenic proposes that arsenic released during weathering is absorbed onto neoformed ferric oxyhydroxides. During burial, bacteria use available organic matter to reductively dissolve the ferric oxyhydroxide grain coatings and release the arsenic to solution (Nickson et al., 2000; 
Berg et al., 2001; BGS and DPHE, 2001; Harvey et al., 2002; Islam et al., 2004; van Geen et al., 2004; Islam et al., 2005). Arsenic release by in situ oxidation of sulfide minerals in response to lowering water levels has been proposed but largely dismissed because of the lack of correlation of arsenic with dissolved sulfate (Acharyya, 2002). Independent of origin, the fate of dissolved arsenic in ground water is incompletely known. Arsenic-rich ground water either directly discharges into the Bay of Bengal or as base flow into rivers, which results in eventual flushing of labile arsenic from the aquifers. Alternatively, arsenic may be retained in the sediment in authigenic iron sulfide minerals. Both flushing and trapping of arsenic in sulfides would support the use of 'deeper' aquifers as a source of safer drinking water but risk evaluation would be markedly different depending on the relative importance of these two processes.

Although iron sulfide has been recognized as a constituent of the sediment in the Bengal Basin (Chatterjee et al., 1995; Nickson et al., 2000; BGS and DPHE, 2001; Acharyya, 2002; Stuben et al., 2003; Akai et al., 2004; McArthur et al., 2004; Swartz et al., 2004; Polizzotto et al., 2005; Ravenscroft et al., 2005), its relative importance and relation to the extensive arsenic-contaminated ground water in south and southeast Asia has not been fully evaluated. This study presents new information on the vertical variations in the abundance and morphology of iron sulfide, its arsenic content, sulfur isotope composition, and factors controlling its formation in shallow and deep sediment in southern Bangladesh.

\subsection{Setting}

The sediment underlying the villages of Rajoir and Srirampur in Bangladesh (Fig. 1) were selected to evaluate

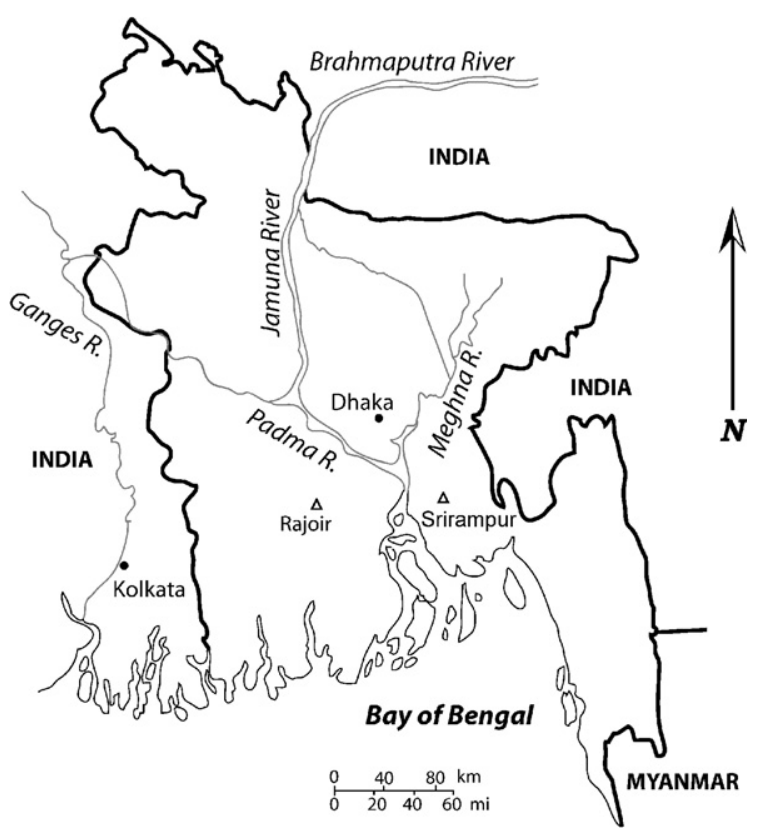

Fig. 1. Map of Bangladesh with location of study areas $(\triangle)$ and major cities $(\bullet)$. the ability of deeper $(>150 \mathrm{~m})$ aquifers to provide safe drinking water. The town of Rajoir (N 23.206; E 90.049), in the Rajoir upazila, Madaripur district, is $30 \mathrm{~km}$ south of the Padma River and $50 \mathrm{~km}$ west of the Meghna River. It is located on the lower Ganges floodplain and is typical of As-contaminated areas located on regularly flooded and actively aggrading floodplains. According to results presented by the National Arsenic Mitigation Information Center (NAMIC), approximately $71 \%$ of the 1340 wells tested within $3 \mathrm{~km}$ of the town of Rajoir exceed the Bangladesh drinking water standard of $50 \mu \mathrm{g} / \mathrm{L}$; similar frequency of high dissolved arsenic is reported for the greater Rajoir upazila (75\% of 13,000 wells) (www.bwspp.org/ photo_albam.html\#screening\%20Resulat). Srirampur (N 23.339; E 90.922) is a village in Kachua upazila, Chandphur district, $30 \mathrm{~km}$ east of the Meghna River. It is located on the lower delta and is part of the extensive flood basin considered part of the Meghna Estuary. The Srirampur borehole was located on alluvium whose surface is above normal levels of flooding, but may be inundated during an unusually large flood. Wells near Srirampur typically contain $>50 \mu \mathrm{g} / \mathrm{L}$ dissolved arsenic $(99 \%$ of 3300 wells tested), which is similar to the $98 \%$ reported for the nearly 18,000 wells tested in the Kachua upazila (www.bwspp.org/ photo_albam.html\#screening\%20Resulat). The high proportion of contaminated wells highlights the critical need for alternative supplies of drinking water in both areas.

As indicated by Ravenscroft et al. (2005), the stratigraphy of the Bengal Basin is poorly described. High Himalayan crystalline rocks have been the dominant source of sediment to the Bengal Basin since the Miocene. The thickness of sediment sampled for this study $(450 \mathrm{~m})$ is inferred to have been deposited mainly in the Quaternary, though Pliocene deposits may be present. The sediment sampled likely was deposited in a range of environments evident in the modern Bengal Basin. Fluvial channel, flood plain, estuarine, and deltaic deposits are stacked vertically and transition laterally. The complex spatial variability is attributed to changes in sea level, glaciation, tectonics and shifting river courses. Differences in the physical and chemical conditions of each of the depositional settings have been proposed to explain the kilometer-scale spatial heterogeneity of dissolved arsenic concentrations (van Geen et al., 2003, 2006; McArthur et al., 2004).

\section{METHODS}

\subsection{Sampling}

Sediment samples were collected from active sand bars in the Meghna and Padma rivers; from 4 hand-dug excavations $<5 \mathrm{~m}$ deep; and from cored intervals of two boreholes drilled to depths up to $450 \mathrm{~m}$ during 2003 and 2004 at Rajoir and Srirampur (Fig. 1). Sand bars were sampled using local watercraft. Shallow excavations included in this study were sampled where encountered during fieldwork within $5 \mathrm{~km}$ of the borehole locations.

Procedures used during sediment collection and chemical analyses are summarized below and presented in greater detail in Breit et al. (2006, 2007). Selected depth intervals of 
borehole sediment were recovered using a Shelby tube or split-spoon sampler. Bulk samples of shallow and borehole sediment were stored in plastic bags and air-dried. Subsamples were collected by inserting a detipped syringe into the core barrel to extract sediment prior to contact with air and transferring the sediment into a glass vial purged with flowing argon gas. The vials were promptly closed, flushed with additional argon through the septa, sealed with electrical tape, frozen in the field, and stored in a freezer (approximately $-20^{\circ} \mathrm{C}$ ) until shipment to the United States for analysis. The samples thawed during transport ( $\sim 1$ week) but upon arrival were purged with high-purity nitrogen and refrozen. Because of the sampling method, results of the analyses of the preserved samples do not correspond directly to the bulk sample analyses.

\subsection{Chemical analyses}

Chemical composition of the sediment was determined by bulk analysis and chemical extractions. Chemical composition of the 115 bulk, air-dried sediment samples was determined by combustion, inductively-coupled plasma-atomic emission spectrometry, energy dispersive X-ray fluorescence, and hydride generation atomic absorption spectrophotometry (HGAAS) using methods described in Taggart (2002). Results of the chemical and mineralogical analyses of the Srirampur and Rajoir borehole samples are presented in Breit et al. (2006, 2007). Total sulfur concentrations were corrected for barite contamination from drilling mud in samples collected below $230 \mathrm{~m}$ (Breit et al., 2006, 2007).

Chemical extractions used to determine the abundance of iron species and sulfide forms are described in detail in Breit et al. (2006, 2007). Sequential iron extractions followed the general method of Heron and Christensen (1995) with the addition of an oxidative treatment to dissolve sulfide phases. Acid-soluble phases were extracted by treating 2-4 g of 82 sediment samples from Rajoir and Srirampur with $40 \mathrm{~mL}$ of $0.5 \mathrm{~N} \mathrm{HCl}$ in a sealed amber glass vial purged with high-purity nitrogen. Vials were shaken intermittently and stored in the dark for $24 \mathrm{~h}$. Solutions were withdrawn with a syringe, filtered through a $0.2 \mu \mathrm{m}$ filter and analyzed immediately with ortho-phenanthroline (Clesceri et al., 1998) to measure ferrous and total dissolved iron. Wilkin and Ford (2002) described the precipitation of arsenic sulfides as a likely result of extracting arsenic from sulfidic sediment using $\mathrm{HCl}$. Evaluation of the content of AVS sulfide and arsenic extracted by $0.5 \mathrm{~N} \mathrm{HCl}$ determined that reprecipitation is likely for only two samples from the Srirampur borehole and one from Rajoir (Breit et al., 2006, 2007). Srirampur sediment remaining after the $0.5 \mathrm{~N} \mathrm{HCl}$ extraction was thoroughly rinsed with deionized water, air-dried and reacted for $24 \mathrm{~h}$ with a solution of $0.008 \mathrm{M}$ $\mathrm{TiCl}_{3}$ and $0.05 \mathrm{M}$ EDTA at $\mathrm{pH} 6.5$ to dissolve crystalline ferric oxides in a $50 \mathrm{~mL}$ serum vial purged with nitrogen. A mechanically split $0.5 \mathrm{~g}$ fraction of the solid residue of the $\mathrm{TiCl}_{3}$-EDTA extraction was treated with warm $20 \%$ hydrogen peroxide in $2 \mathrm{~N} \mathrm{HCl}$ to dissolve sulfide phases. HGAAS and hydride generation atomic fluorescence spectroscopy were used to determine arsenic concentrations in extraction solutions.
AVS acid-soluble sulfate and $\mathrm{Cr}^{2+}$ reducible sulfide (pyrite) were extracted from 28 samples with relatively high bulk-sulfur contents using the procedures of Tuttle et al. (1986) as modified by Rice et al. (1993). Samples first were treated with $6 \mathrm{~N} \mathrm{HCl}$ amended with stannous chloride to recover AVS (FeS and greigite) and acid-soluble sulfate. The AVS residue was mixed with a solution of $4 \mathrm{~N} \mathrm{HCl}$ and $1 \mathrm{M} \mathrm{CrCl}_{2}$ to extract pyrite. Sulfide was precipitated as $\mathrm{Ag}_{2} \mathrm{~S}$ and sulfate as $\mathrm{BaSO}_{4}$ for gravimetric measurement of sulfur forms and isotope analyses. The sulfur isotope composition of fertilizer and barite additive to drilling mud were also determined by dissolution and precipitation as $\mathrm{BaSO}_{4}$. Sulfur isotope analyses followed the procedures of Kester et al. (2001).

\subsection{X-ray absorption fine structure spectroscopy (XAFS)}

Seven borehole samples for bulk XAFS analyses were kept frozen in inert-gas purged, sealed amber vials until shortly before analysis at the beamline (approximate holding time: 1-2 h). Each sample was transferred into an anaerobic chamber for processing and loading. Sediments were ground (coarser material) or mixed in a mortar and pestle prior to loading into a $3 \mathrm{~mm}$ thick Teflon cell sealed with Mylar tape and placed onto an aluminum holder. The loaded sample was removed from the chamber, immediately dipped into liquid nitrogen, and kept frozen until analysis. Two subsamples from the Srirampur borehole (SH1-4, $39 \mathrm{~m}$ and SH1-36, $324 \mathrm{~m}$ ) were prepared for microbeam XAS as described in Walker et al. (2005). A subset of the model compounds described below was analyzed as powders placed in glass capillaries or as single grains attached to Mylar tape for data calibration and comparison of resolution differences between beamlines.

Mineral model compounds were diluted and prepared for bulk and microXAFS analysis as previously described (Foster et al., 1998b). Arsenite $\left(\mathrm{As}^{\mathrm{III}} \mathrm{O}_{3}\right)$ and arsenate $\left(\mathrm{As}^{\mathrm{V}} \mathrm{O}_{4}\right)$ coprecipitates in vivianite $\left(\mathrm{Fe}_{3}\left(\mathrm{PO}_{4}\right)_{2} \cdot 8 \mathrm{H}_{2} \mathrm{O}\right)$ and siderite $\left(\mathrm{FeCO}_{3}\right)$, and adsorption samples on hydrous ferric oxide (HFO) were prepared in an anaerobic chamber $(3 \%$ $\mathrm{H}_{2} / 97 \% \mathrm{~N}_{2}$ ) using oxygen-free solutions. Vivianite coprecipitates were protected from light to prevent oxidation. All ferrous mineral-arsenic coprecipitates were frozen immediately after synthesis and analyzed at low temperature to preclude ferrous iron oxidation. Coprecipitates of arsenic oxyanions in hydrous aluminum oxide (HAO) were prepared as described in Foster (1999).

Arsenic K-edge XAFS spectra of bulk samples were collected at the Stanford Synchrotron Radiation Laboratory (SSRL; ring conditions: $3 \mathrm{GeV}$ and $50-90 \mathrm{~mA}$ ) on beamline 11-2 over varying energy ranges $(11,635-12,900 \mathrm{eV}$ for high concentration model compounds and 11,635-11,920 eV for low-concentration borehole sediment) using a $\mathrm{Si}(220)$ monochromator and a 13- or 30-element germanium detector (Foster et al., 1998a). XAFS spectra of borehole samples and oxygen-sensitive model compounds (e.g. arsenite sorption samples) were collected at $10 \mathrm{~K}$ using a liquid helium-cooled cryostat. A comparison of spectra collected at ambient and low temperature revealed no difference in spectral line shape over the energy range used in this analysis. 
Spatially-resolved XAFS (microXAFS) spectra and spatially-resolved X-ray fluorescence (microXRF) maps were collected under ambient conditions on beamline 10.3.2 at the Advanced Light Source (Berkeley, CA). MicroXAFS spectra of model compounds and samples were collected over the energy range $11,767-12,167 \mathrm{eV}$. The X-ray beam was $300 \times 50 \mu \mathrm{m}$ for maps and $300 \times 20 \mu \mathrm{m}$ for spots using the conditions described in Marcus et al. (2004). The pixel size was $20 \times 20 \mu \mathrm{m}$ for maps with a scan speed of $200 \mu \mathrm{m} / \mathrm{s}$ and a dwell time was $200 \mathrm{~ms}$.

The method of XAFS data analysis was similar to that used in recent studies (Slowey et al., 2005). Data averaging (bulk XAFS spectra), data reduction (all spectra), and least squares fitting (all spectra) were accomplished using SixPACK (Webb, 2002); microXAFS spectra were averaged using "EXAFS editor.exe" and microXRF maps were viewed and interpreted using "XY display with mask.exe" developed by M. Marcus (ALS). Quantitative analysis of the identity and abundance of arsenic species was ascertained by linear combination least-squares fits of model spectra representing arsenic in a variety of coordination environments to X-ray absorption near edge structure (XANES) spectra (for bulk sediments with low arsenic) or extended XANES spectra (for microbeam spots with higher arsenic). The accuracy of the fit procedure is approximately 10\% (Foster et al., 1998a), but may be lower based on the signal-to-noise ratio of the analyzed spectrum. The operational detection limit of minor As species in bulk As K-edge XANES spectra is approximately 8\% (Foster et al., 1998a). Details of the procedures used for spectral fits are given in electronic annex (EA) Appendix 1.

\subsection{Electron microscopy methods}

Twenty epoxy impregnated grain mounts were prepared for examination and analysis of sulfide mineral grains using a scanning electron microscope (SEM) and electron probe microanalyzer (EPMA). Preserved subsurface samples representing oxidized unsaturated zone, the top of the dry-season saturated zone, and deeper sediment were freeze-dried prior to impregnation. Surficial river sediments and mica separates from deeper, air-dried sediments were also mounted. Sample orientation and bedding features were not preserved during mounting.

A JEOL-5800LV SEM equipped with an Oxford ISIS energy dispersive X-ray spectrometer (EDS) was operated at $20 \mathrm{keV}$ and $0.1-1 \mathrm{nA}$ current with a $10 \mathrm{~mm}$ sample working distance during analysis of these samples. The operational detection limit for arsenic in pyrite under these analytical conditions was approximately $8000 \mathrm{ppm}$. Secondary and backscattered electron imaging were used to observe textural and chemical variations within pyrite grains. Oxford ISIS digital imaging software was used to measure dimensions of the pyrite grains.

Following textural observations with the SEM, 156 sulfide mineral grains in eight samples were analyzed with a fully automated, five-wavelength spectrometer JEOL 8900 EPMA. Operating conditions were $10 \mathrm{keV}$ accelerating voltage, $30 \mathrm{nA}$ beam current (cup), and focused beam. A $10 \mathrm{keV}$ accelerating voltage was selected to reduce the analysis volume to approximately $1 \mu \mathrm{m}$, based on Monte Carlo simulations. Fe, $\mathrm{S}, \mathrm{As}, \mathrm{Cu}$, and $\mathrm{Zn}$ concentrations were quantified using peak counting times of $10 \mathrm{~s}$ for $\mathrm{Fe}$ and $\mathrm{S}$ and $60 \mathrm{~s}$ for $\mathrm{As}, \mathrm{Cu}$, and $\mathrm{Zn}$. Upper and lower background counting times were half the peak count times for the respective elements. L $\alpha$ X-ray lines were analyzed for $\mathrm{As}, \mathrm{Cu}$, and $\mathrm{Zn}$. Si and $\mathrm{Mg}$ were measured concurrently with EDS. Although the calculated As detection limit is approximately $100 \mathrm{ppm}$ using the above conditions, values below 300 ppm were not reproducible, so an effective detection limit of $300 \mathrm{ppm}$ was assigned. Precision of As measurements are within 3\% relative. All data points containing $\mathrm{Mg}$ and $\mathrm{Si}$, most likely intergrown clays, were removed from the data set because of the known interference of $\mathrm{As} \mathrm{L} \alpha$ radiation with $\mathrm{Mg} \mathrm{K} \alpha$ radiation.

\section{RESULTS}

\subsection{Bulk sediment characteristics}

Sediment recovered from the boreholes and surface at Rajoir and Srirampur are typically gray in color with a few notable exceptions. Active river sediment and shallow sediment collected during the dry season (January-April) are yellow-brown through the unsaturated zone $(2-4 \mathrm{~m}$ depth) (Breit et al., 2004). Intervals of deeper, yellow-brown sediment were recovered from both the Srirampur $(46 \mathrm{~m})$ and Rajoir boreholes $(305 \mathrm{~m})$. These brown sediments are attributed to erosional unconformities such as that recognized at the end of the Pleistocene (Umitsu, 1993).

Regardless of color, all sediment recovered is micaceous feldspathic arenite. Quartz is the most abundant mineral with minor amounts of plagioclase, potassium feldspar, biotite, chlorite and muscovite (Breit et al., 2006, 2007). The abundances of micas and chlorite increase with decreasing grain size. Constituents of the $<2 \mu \mathrm{m}$ fraction include mica/illite, chlorite, smectite, and kaolinite. Authigenic phases recognized during SEM examination of grain mounts include goethite in the brown sediment and pyrite, siderite and iron phosphate (vivianite?) in gray samples. The sediment is mainly medium to fine sand but ranges from clay to pebbly coarse sand. Borehole sediment collected at Rajoir is generally coarser than that recovered at Srirampur (Fig. 2).

Total arsenic, organic carbon, sulfur, and the amount of iron dissolved by the $0.5 \mathrm{~N} \mathrm{HCl}$ extractions $\left(\mathrm{Fe}_{\mathrm{HCl}}\right)$ are significantly greater in the Srirampur sediment than that recovered at Rajoir (Table 1). Total arsenic does not vary systematically with depth in either borehole (Fig. 2). Arsenic content is generally more abundant in sediments that contain larger amounts of sulfur, organic carbon and silt and clay $(<62 \mu \mathrm{m})$. A strong correlation of arsenic with abundance of silt and clay is evident in the Rajoir borehole but is not apparent in the Srirampur sediment samples. Similar organic carbon-arsenic associations are indicated elsewhere in Bangladesh (JICA, 2002; Meharg et al., 2006). Nonetheless, the best interelement correlation for arsenic is with sulfur $\left(r^{2}=0.56 ; p<0.001\right.$; excluding outliers with $>50 \mathrm{ppm}$ arsenic that greatly increased $r^{2}$ ). The association of arsenic and sulfur varies vertically within 
Rajoir
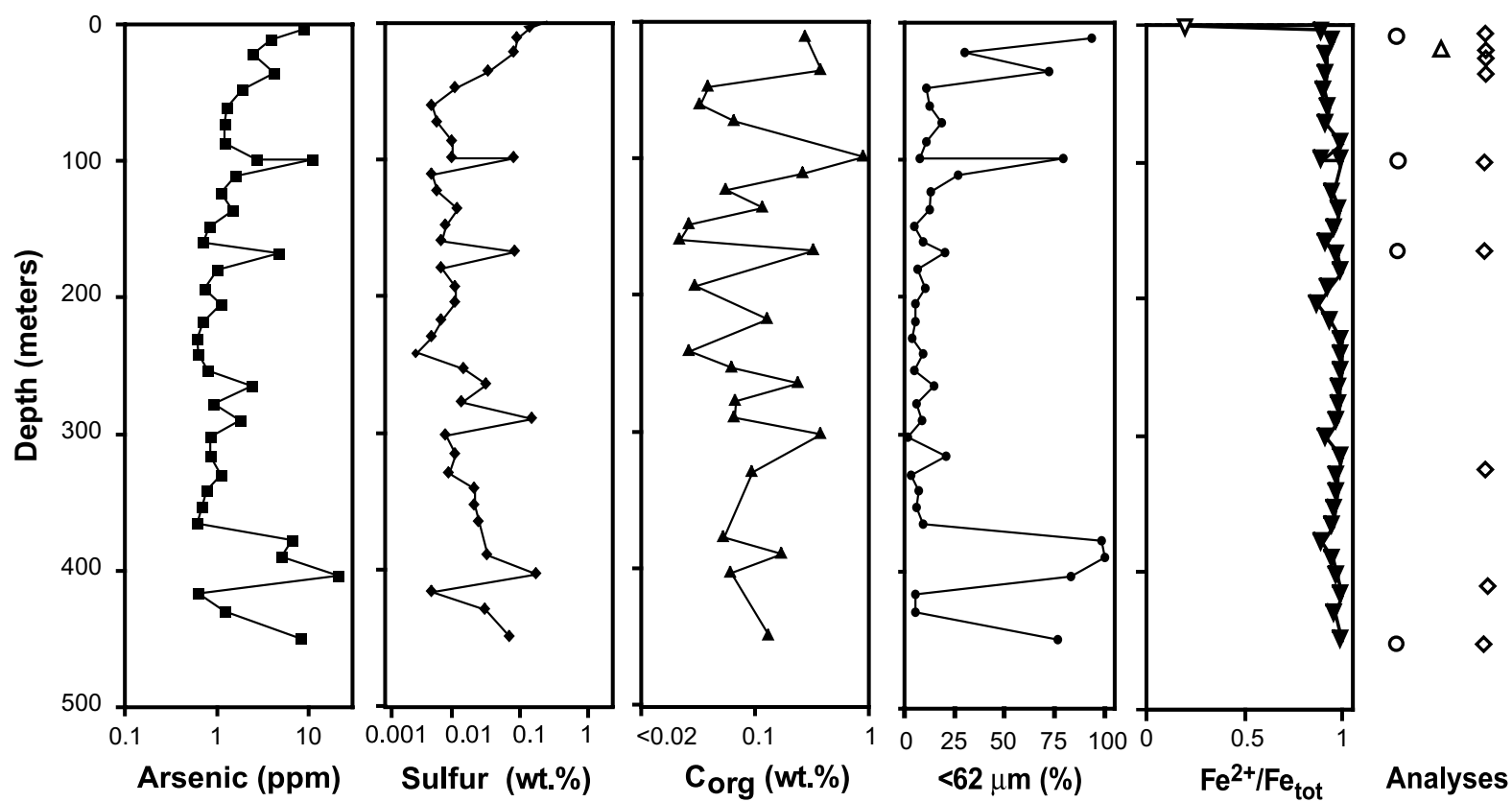

\section{Srirampur}
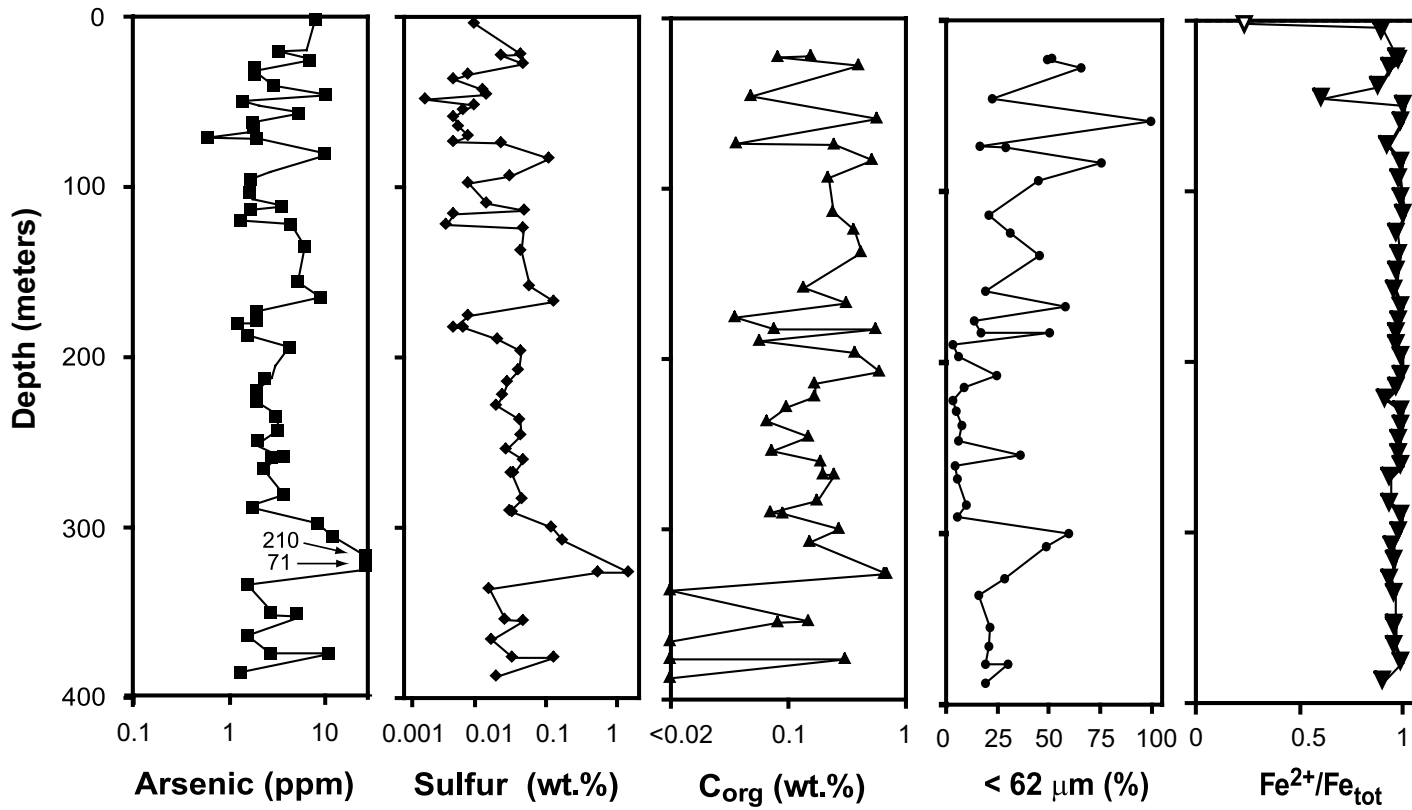

은

$\Delta$

$\Delta$

$\Delta \diamond$

0

$$
\begin{aligned}
& \diamond \\
& \diamond \\
& \diamond \\
& \diamond \\
& \diamond
\end{aligned}
$$

$\diamond$

$\Delta \diamond$

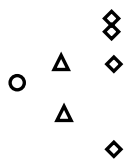

Analyses

Fig. 2. Total arsenic, total sulfur, organic carbon (Corg), the content of silt and clay $(<62 \mu \mathrm{m})$, and the ratio of $0.5 \mathrm{~N} \mathrm{HCl} \mathrm{extractable} \mathrm{Fe}^{2+} /$ $\mathrm{Fe}_{\text {total }}$ in sediment samples from Rajoir and Srirampur. Symbols on the right indicate samples analyzed using electron probe $(\bigcirc)$, XAFS $(\nabla)$ and sulfur speciation analyses $(\diamond)$ of preserved samples. $\left(\triangle\right.$-sample from the unsaturated zone for determination of $\left.\mathrm{Fe}^{2+} / \mathrm{Fe}_{\text {total }}\right)$.

the boreholes as evident by variations in the ratio of arsenic and sulfur (Fig. 3).

The abundance of sulfur in the surficial and shallowest samples is directly related to the degree of water saturation. Sediment collected from surface excavations showed that saturated, gray sediment contains greater sulfur concentrations (median $=0.012 \mathrm{wt} . \%, n=6$ ) than overlying unsaturated, brown sediment (median $<0.005 \mathrm{wt} . \%, n=8$ ) and active river sediment $(<0.005 \mathrm{wt} . \%)$. Sediment collected
$0.5 \mathrm{~m}$ below the shallow gray-brown interface at Rajoir contains 0.14 wt. $\%$ sulfur while sediment at a similar depth in Srirampur contains 0.01 wt. \% sulfur.

Gray sediment from both study areas contains high contents of iron soluble in $0.5 \mathrm{~N} \mathrm{HCl}$ (Table 1), which consistently has a $\mathrm{Fe}^{2+} / \mathrm{Fe}_{\text {total }}$ ratio greater than 0.85 (Fig. 2; Breit et al., 2006, 2007) similar to previous results reported on sediments from elsewhere in Bangladesh (Horneman et al., 2004; van Geen et al., 2006). Much of the extracted 
Table 1

Chemical composition of sediment from Rajoir and Srirampur

\begin{tabular}{|c|c|c|c|c|c|c|c|c|}
\hline \multirow[t]{2}{*}{ Element } & \multicolumn{4}{|l|}{ Rajoir } & \multicolumn{4}{|c|}{ Srirampur } \\
\hline & Median & Minimum & Maximum & Number & Median & Minimum & Maximum & Number \\
\hline As (ppm) & 1.3 & 0.61 & 21 & 42 & 2.8 & 0.6 & 290 & 59 \\
\hline S (wt. $\%)$ & 0.012 & $<0.005$ & 0.17 & 38 & 0.027 & $<0.005$ & 1.5 & 58 \\
\hline Corg (wt.\%) & 0.07 & 0.02 & 0.91 & 25 & 0.18 & 0.04 & 0.66 & 35 \\
\hline $\mathrm{Fe}_{\mathrm{HCl}}^{2+}(\mathrm{wt} . \%)$ & 0.37 & 0.08 & 1.7 & 36 & 0.66 & 0.13 & 6.3 & 43 \\
\hline
\end{tabular}

$\left(\mathrm{Fe}_{\mathrm{HCl}}^{2+}\right.$, ferrous iron extracted by treatment of sediment with $\left.0.5 \mathrm{~N} \mathrm{HCl}\right)$.

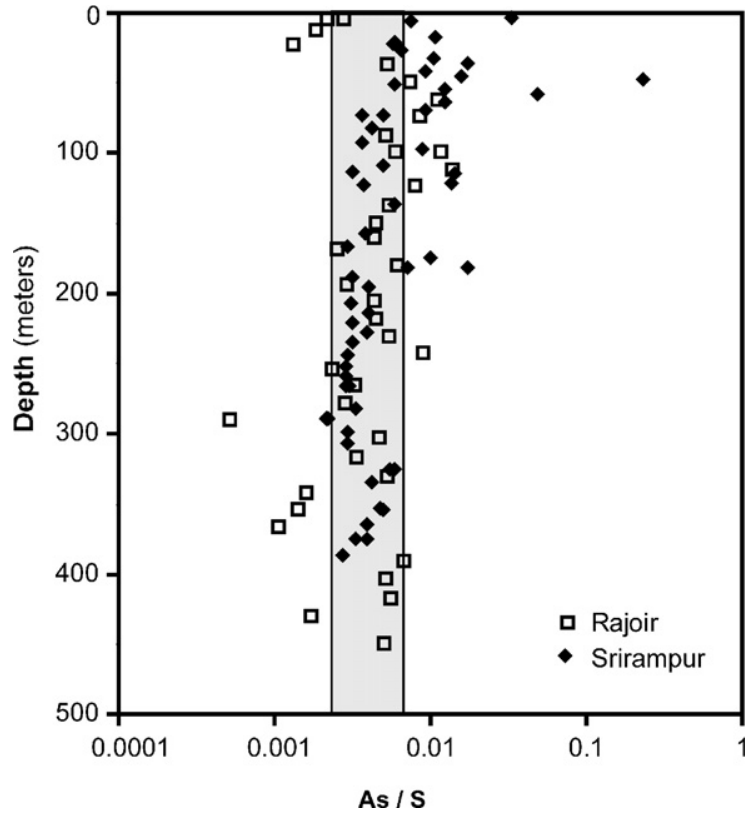

Fig. 3. Mole ratio of arsenic to sulfur in bulk sediment samples. The shaded area corresponds to As:S ratios of most pyrite analyzed in this study. The maximum amount of arsenic measured in pyrite corresponds to a ratio of 0.009 .

iron is attributed to fine-grained siderite that was detected by XRD and SEM (Breit et al., 2006, 2007). The abundance of ferrous iron in the gray sediment contrasts with the content in the sediment within a few meters of the ground surface which typically has $\mathrm{Fe}^{2+} / \mathrm{Fe}_{\text {total }}$ ratios $<0.2$ (Breit et al., 2004). Buried brown sediment typically has a ratio $<0.5$ (Horneman et al., 2004) but in this study was found to be $<0.8$ (Breit et al., 2006). The amount of total iron extracted by $0.5 \mathrm{~N} \mathrm{HCl}\left(\mathrm{Fe}_{\mathrm{HCl}}^{2+}\right)$ was used to approximate the degree of sulfidization assuming that all of the measured bulk sulfur was contained in pyrite. The ratio of $\mathrm{Fe}_{\text {pyrite }} / \mathrm{Fe}_{\mathrm{HCl}}^{2+}$ ranged from 0.004 to 0.5 with a median of 0.1 , which indicates that all samples contain iron in excess of that needed to form pyrite. The amount of iron extractable by $\mathrm{Ti}^{3+}$-EDTA from the Srirampur sediment was consistently $<20 \%$ of the iron extracted by $0.5 \mathrm{~N} \mathrm{HCl}$ (Breit et al., 2006).

The amount of arsenic chemically extracted from the Srirampur sediment is summarized in Fig. 4. The lack of specificity of chemical extractions limits interpretation but the contrast in measured arsenic abundances among the extracts is consistent with other analyses used in this study.
The arsenic in the $0.5 \mathrm{~N} \mathrm{HCl}$ extracts may reflect absorbed arsenic and that bound in siderite and vivianite as suggested by the XAFS data (discussed in Section 3.3). The release of arsenic by a reductive extraction $\left(\mathrm{Ti}^{3+}\right.$-EDTA) supports the presence of residual ferric oxides in the sediment. Samples from depths $<120 \mathrm{~m}$ tend to contain arsenic extractable by $\mathrm{Ti}^{3+}$-EDTA that is either greater than or equal to the amount extracted by $0.5 \mathrm{~N} \mathrm{HCl}$, which contrasts with the results from the deeper samples. The median content of arsenic dissolved by $\mathrm{Ti}^{3+}$-EDTA was $22 \%$ of the total extracted arsenic in sediment $<120 \mathrm{~m}$, while the median value in deeper sediment was $9 \%$. In nearly all gray sediments, the oxidative extraction of $\mathrm{H}_{2} \mathrm{O}_{2}-\mathrm{HCl}$ dissolved

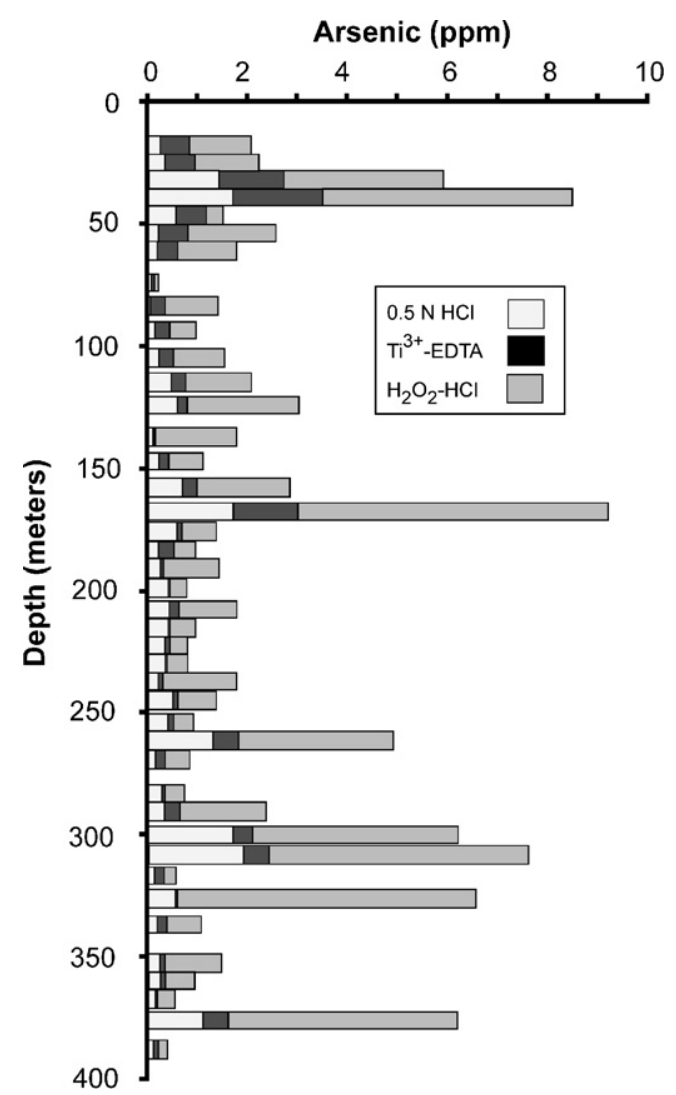

Fig. 4. The concentration of arsenic sequentially extracted from preserved sediment samples collected from the Srirampur borehole. The extracts include $0.5 \mathrm{~N} \mathrm{HCl}$ (exchangeable species, siderite and vivianite); $\mathrm{Ti}^{3+}$-EDTA, (ferric oxides); and $\mathrm{H}_{2} \mathrm{O}_{2}-\mathrm{HCl}$ (sulfide phases). 
more arsenic than the other extractions, which is consistent with the greatest content of arsenic in sulfide phases (Fig. 4).

\subsection{Sulfur speciation and sulfur isotope composition}

The abundances of AVS, pyritic sulfur (PY), and acidsoluble sulfate and their isotopic compositions are summarized in Fig. 5 and listed in Table EA-1. Pyritic sulfur abundances vary from 20 to $9580 \mathrm{ppm}$ (Fig. 5a) with the greatest concentrations detected in samples $>100 \mathrm{~m}$ deep at Srirampur. In contrast, the highest pyrite content at Rajoir was measured in the top two samples. Contents of PY are greater than AVS in 23 of 25 samples. The ratio of AVS to PY in samples from Srirampur decreases downward from shallow depths to $150 \mathrm{~m}$. Below $150 \mathrm{~m}$ the ratios are $<0.1$ with the exception of 2 samples (Fig. 5b). These samples are notable for their low content of pyritic sulfur, and therefore the calculated ratios are sensitive to small differences in concentration and analytical error. Sediment from Rajoir has generally greater AVS/PY values than Srirampur samples. Measurable sulfate was recovered from 16 of the 25 samples but at concentrations lower than associated sulfide $(<10$ $130 \mathrm{ppm})$.

$\delta^{34} \mathrm{~S}$ values vary widely with similar ranges for all forms; AVS varies from $-13.8 \%$ to $39.9 \%$, the range for pyrite is $-22.7 \%$ to $32.9 \%$ (Fig. $5 \mathrm{c}$ ), and the acid-soluble sulfate varies from $-13.5 \%$ to $35.3 \%$. Pyrite in 14 samples contains sulfur with an isotopic composition between +6 and $-6 \%$ including the samples at the top of the saturated zone $(-0.4$ and -2.3$)$. Exceptions to this tendency are the two deepest samples from Srirampur and the shallowest borehole sample from Rajoir, which have $\delta^{34} \mathrm{~S}_{\mathrm{PY}}<-9 \%$. These samples also contain the greatest amount of pyritic sulfur of the samples analyzed. Eight samples have $\delta^{34} \mathrm{~S}_{\mathrm{PY}}>+8 \%$ and 6 of these are in the upper $150 \mathrm{~m}$ of the boreholes. The isotopic composition of AVS $\left(\delta^{34} \mathrm{~S}_{\mathrm{AVS}}\right)$ was compared to pyrite $\left(\delta^{34} \mathrm{~S}_{\mathrm{PY}}\right)$ by calculating the difference for each sample (Fig. 5d). The absolute value of the difference for most samples is less than $6 \%$. In four samples from $<50 \mathrm{~m}$ depth, $\delta^{34} \mathrm{~S}_{\mathrm{AvS}}$ is much greater than $\delta^{34} \mathrm{~S}$ values of pyrite. Two samples between 200 and $300 \mathrm{~m}$ depth have $\delta^{34} \mathrm{~S}_{\mathrm{AVS}}$ much less than $\delta^{34} \mathrm{~S}_{\mathrm{PY}} . \delta^{34} \mathrm{~S}_{\mathrm{SO} 4}$ is greater than $14 \%$ for all but one sample at $327 \mathrm{~m}$ depth at Srirampur $(-13.5 \%$ o $)$, which is very similar to the coexisting AVS. Four of the sulfate samples are in the depth range in which contamination from barite in the drilling mud is possible $(>230 \mathrm{~m}$ ) (Breit et al., 2006, 2007). However, the affect of contamination is considered minor because the measured $\delta^{34} \mathrm{~S}$ values are substantially different from the mud additive (Table EA-1).

\subsection{Arsenic valence and solid phase speciation}

The nominal arsenic valence values of Rajoir and Srirampur bulk sediment range from -0.2 to 2.2 (average: 1.1, $n=6$ ) (Fig. 6), which indicates that reduced arsenic is the dominant form in these samples. Arsenate and arsenite typically constitute $<50 \%$ of the total arsenic in bulk XANES and extended microXANES fits (Table 2). Partial oxidation of the samples during handling, transport and storage may account for some or all of the arsenate, but our analyses of the oxidation state of $0.5 \mathrm{~N} \mathrm{HCl}$ soluble iron and the abundance of AVS suggest oxidation was minimal. If the calculated abundance of arsenate in the deeper sediments is correct, then it is likely that some grains contain refractory oxidized arsenic that survived burial in the generally reducing environment of the gray sediment.

Progressive change of arsenic valence in the shallow $(<150 \mathrm{~m}$ depth) Srirampur aquifer sediment is evident in fits of bulk XANES spectra. These spectra integrate over the arsenic residence in hundreds to thousands of grains, including arsenic-rich pyrite that is typically $10-20 \mu \mathrm{m}$ in diameter and the more abundant, lower-arsenic grains of siderite, vivianite, HFO, and potentially other unrecognized
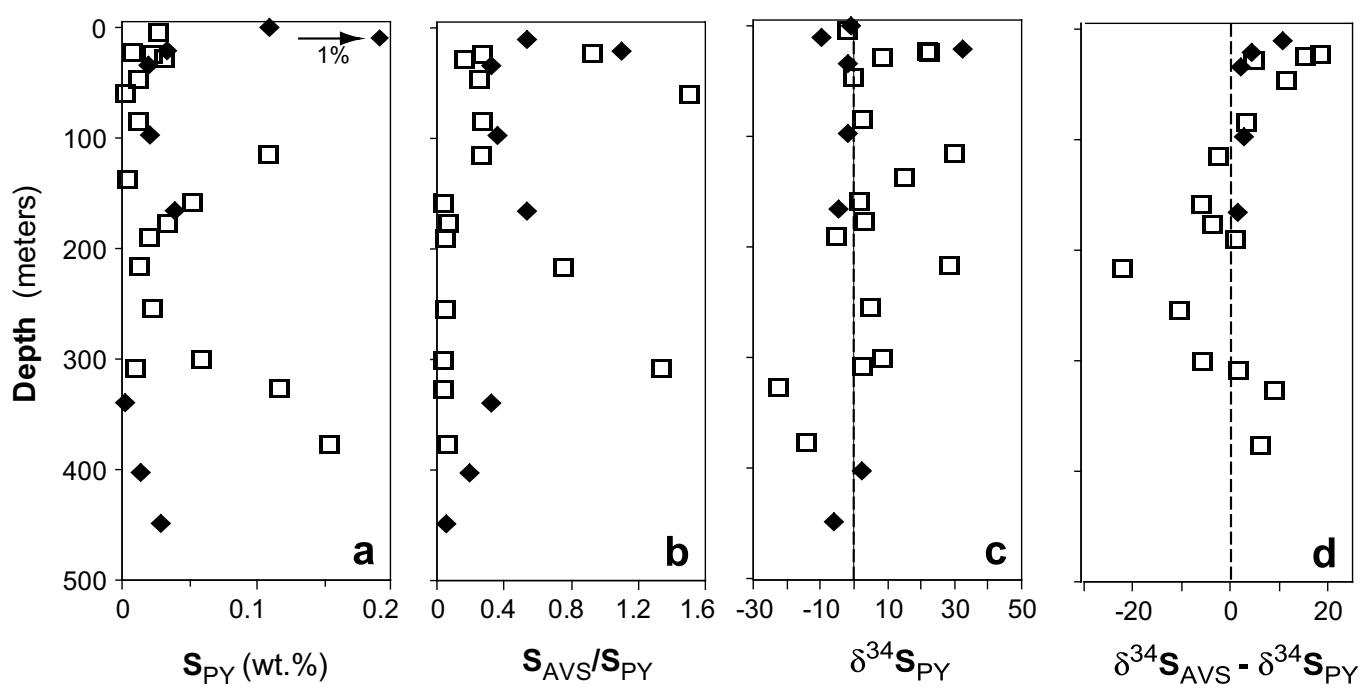

Fig. 5. Mineral sulfide abundance and isotope composition in sediment samples from Rajoir $(\diamond)$ and Srirampur ( $\square$ ). (a) pyritic sulfur (PY), (b) weight ratio of acid-volatile sulfide (AVS) and PY, (c) $\delta^{34} S_{P Y}$ of pyritic sulfur and (d) the difference in the $\delta^{34} \mathrm{~S}$ composition of AVS and PY. 


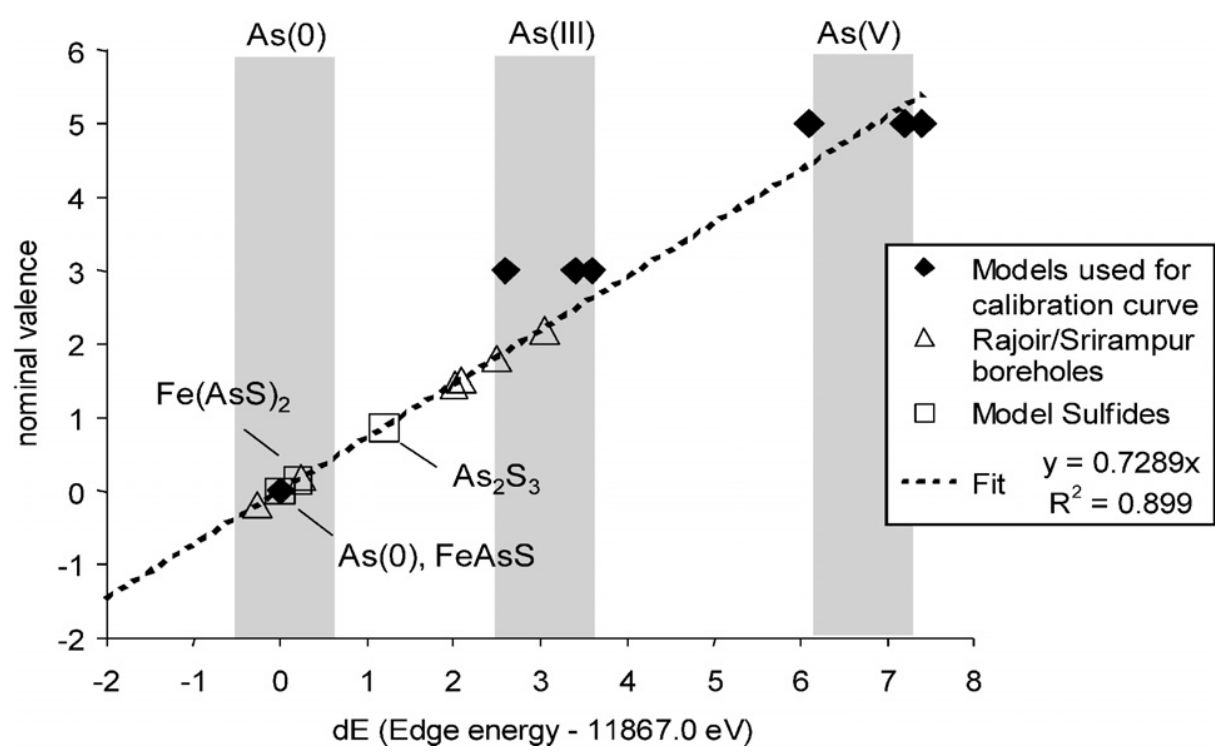

Fig. 6. Energy position of model and bulk borehole XANES spectra. There is a shift of $\sim 3 \mathrm{eV}$ with each increase in nominal oxidation state. Selected models with well-defined oxidation states were used to generate the linear relationship between energy shift and nominal valence that was applied to sulfide model compounds and to samples.

phases that are typically associated with altered iron micas. Analysis of bulk XANES spectra indicates that the amount of sulfide arsenic is at a minimum at $22 \mathrm{~m}$ depth, increases by about $40 \%$ at $83 \mathrm{~m}$, and again by $24 \%$ at $260 \mathrm{~m}$ depths, before leveling off to $71 \%$, whereas arsenate is at a maximum in the shallowest sample, and is significantly less in the deeper samples. The trend for arsenite is less clear but there is a significant increase between 22 and $83 \mathrm{~m}$ depth with generally lower values at greater depth. Overall, these spectra indicate that several phases and oxidation states of arsenic coexist in sediments, but that the relative proportions of these phases and oxidation states change with depth, in concert with overall changes in sediment geochemistry.

The models which minimized $\chi^{2}$ based on a linear combination least-squares fit to bulk XANES and extended microXANES spectra were arsenian pyrite, orpiment, siderite, vivianite, HFO, and HAO (Table 2 and EA Appendix1). The use of arsenian pyrite, siderite, vivianite, and HFO in evaluating the data is consistent with SEM and extraction results (Fig. 4). HAO is justified as a fit component based on the weathering of abundant mica present in the samples. Arsenian pyrite was the most common component detected in sediment with low valent arsenic (Table 2). Orpiment was only detected in a bulk XANES spectrum of a shallow peat layer sampled in an excavation near Rajoir, a bulk XANES spectrum of Srirampur sediment from $29.1 \mathrm{~m}$ depth, and a microXANES spectrum of a grain in Srirampur sediment from $39 \mathrm{~m}$ depth. These findings do not preclude the possibility that both pyrite and orpiment are present in some samples at concentrations below detection (about $5-10 \%$ of the total arsenic). For both the arsenian pyrite and orpiment species determinations, greater confidence is placed in the fits to extended microXANES spectra than fits to the bulk XANES spectra because the latter spectra contain less noise and have more data than the former. The low abundance of arsenite and arsenate solid-phase species and noted similarities among the XANES spectra of many arsenate/arsenite model compounds (Foster, 2003) makes these species assignments less certain.

Extended microXANES spectra from the Srirampur borehole are not representative of the overall arsenic speciation, but they provide the most detailed and reliable information on the identity of the solid-phase species of arsenic. Nearly all of the high As areas displayed on a false-color microXRF map have extended XANES spectra consistent with arsenian pyrite, with a small amount of oxidized arsenate in some spectra (Fig. 7, Table 2). No variation in the arsenian pyrite species could be observed between grains high in sulfur and low in arsenic or vice versa (Fig. 7a and b), but spots low in arsenic and sulfur (such as spot 5 in Fig. 7a, probably a mica grain based on the high $\mathrm{K}$ content) contain more arsenate and/or arsenite relative to arsenian pyrite, although the latter is still detected (see spot 5 XANES spectrum in Fig. 7d). Since the "micro" X-ray beam employed was rather large $(16 \times 7 \mu \mathrm{m})$ relative to the size of the authigenic siderite and vivianite (as estimated from SEM images), it is likely that the spectrum collected at this spot is an integration over several, but not hundreds of discrete grains. Even with the knowledge that the sampling at spot 5 may not be representative of the arsenic speciation as a whole, the agreement is striking between the microXANES spectrum of spot 5 and the bulk sediment XANES spectrum from the same depth horizon, and suggests that this modal proportion of arsenic species is probably the most representative of the sample as a whole.

The arsenite and arsenate-bearing model compounds providing the best fits to the oxidized arsenic in extended 
Table 2

Abundance of arsenic-containing phases indicated by analyses of XANES spectra of bulk samples and individual grains

\begin{tabular}{|c|c|c|c|c|c|c|c|c|c|}
\hline \multirow[t]{2}{*}{ Sample } & \multirow[t]{2}{*}{ Depth $(\mathrm{m})$} & \multirow[t]{2}{*}{ As $(\mathrm{mg} / \mathrm{kg})$} & \multirow[t]{2}{*}{ Edge position $^{\mathrm{a}}(\mathrm{eV})$} & \multirow[t]{2}{*}{ Fit range $(\mathrm{eV})$} & \multicolumn{3}{|c|}{ Percent of model compound (not normalized) ${ }^{\mathrm{b}}$} & \multirow[t]{2}{*}{ Energy shift (eV) } & \multirow[t]{2}{*}{$\chi^{2 \mathrm{c}}$} \\
\hline & & & & & Sulfide & Arsenite model & Arsenate model & & \\
\hline \multicolumn{10}{|c|}{ Srirampur borehole Ar-preserved sediment (bulk XANES) } \\
\hline SH1-1 & 21.9 & 7 & 11869.1 & 60 & $22 \mathrm{As}_{2} \mathrm{~S}_{3}$ & $32(\mathrm{HAO})$ & 33 (HAO) & -0.8 & 16.7 \\
\hline SH1-9 & 83.2 & 10 & 11870.1 & 60 & $54 \mathrm{Fe}(\mathrm{As}, \mathrm{S})_{2}$ & 44 (HFO) & & -0.7 & 10.0 \\
\hline SH1-29 & 260.6 & 4 & 11869.2 & 60 & $73 \mathrm{Fe}(\mathrm{As}, \mathrm{S})_{2}$ & 13 (HAO) & 11 (HAO) & -1.6 & 4.5 \\
\hline SH1-36 & 326.1 & 74 & 11867.3 & 60 & $72 \mathrm{Fe}(\mathrm{As}, \mathrm{S})_{2}$ & 9 (siderite) & 19 (HFO) & 0.2 & 0.3 \\
\hline SH1-39 & 355.1 & 6 & 11866.7 & 60 & $68 \mathrm{Fe}(\mathrm{As}, \mathrm{S})_{2}$ & 15 (siderite) & 16 (HFO) & -0.8 & 6.7 \\
\hline \multicolumn{10}{|c|}{ Rajoir borehole Ar-preserved sediment (bulk XANES) } \\
\hline SH2-1 & 11.6 & 10 & 11869.1 & 60 & $81 \mathrm{Fe}(\mathrm{As}, \mathrm{S})_{2}$ & & $\begin{array}{l}11 \text { (ferric phosphate, } \\
\text { amorphous) }\end{array}$ & -1.2 & 6.4 \\
\hline $\begin{array}{l}\text { Rajoir Peat, surface } \\
\text { pit }\end{array}$ & 3 & 4 & 11869.5 & 60 & $48 \mathrm{As}_{2} \mathrm{~S}_{3}$ & 43 (vivianite) & 14 (vivianite) & -0.09 & 2.6 \\
\hline \multicolumn{10}{|c|}{ Srirampur $39 \mathrm{~m}$ microXANES } \\
\hline Area 1, spot1 & 39 & n.d. & 11866.6 & 90 & $113 \mathrm{Fe}(\mathrm{As}, \mathrm{S})_{2}$ & & & 0.6 & 1.9 \\
\hline Area 1, spot 2 & 39 & n.d. & 11866.4 & 90 & $102 \mathrm{Fe}(\mathrm{As}, \mathrm{S})_{2}$ & & & 0.8 & 2.0 \\
\hline Area 1 , spot 10 & 39 & n.d. & 11869.1 & 90 & & 70 (siderite) & 34 (siderite) & 0.5 & 59.2 \\
\hline Area 1, spot 11 & 39 & n.d. & 11866.0 & 90 & $38 \mathrm{As}_{2} \mathrm{~S}_{3}$ & 56 (vivianite) & 10 (vivianite) & 0.9 & 1.7 \\
\hline Area 2, spot 1 & 39 & n.d. & 11866.4 & 90 & $98 \mathrm{Fe}(\mathrm{As}, \mathrm{S})_{2}$ & & 3 (siderite) & 0.2 & 2.5 \\
\hline Area 2, spot 2 & 39 & n.d. & 11865.7 & 50 & $87 \mathrm{Fe}(\mathrm{As}, \mathrm{S})_{2}$ & & 15 (HFO) & -0.2 & 4.0 \\
\hline \multicolumn{10}{|c|}{ Srirampur 326 m microXANES } \\
\hline Spot 1 & 326.1 & n.d. & 11865.7 & 250 & $99 \mathrm{Fe}(\mathrm{As}, \mathrm{S})_{2}$ & & & 0.7 & 2.6 \\
\hline Spot 2 & 326.1 & n.d. & 11866.1 & 250 & $100 \mathrm{Fe}(\mathrm{As}, \mathrm{S})_{2}$ & & & 0.4 & 3.2 \\
\hline Spot 6 & 326.1 & n.d. & 11866.2 & 250 & $100 \mathrm{Fe}(\mathrm{As}, \mathrm{S})_{2}$ & & & 0.2 & 3.0 \\
\hline Spot 3 & 326.1 & n.d. & 11866.2 & 250 & $90 \mathrm{Fe}(\mathrm{As}, \mathrm{S})_{2}$ & & 10 (HFO) & -0.5 & 2.0 \\
\hline Spot 4 & 326.1 & n.d. & 11866.6 & 250 & $90 \mathrm{Fe}(\mathrm{As}, \mathrm{S})_{2}$ & 3 (siderite) & 7 (siderite) & -0.8 & 2.5 \\
\hline Spot 5 & 326.1 & n.d. & 11866.3 & & $76 \mathrm{Fe}(\mathrm{As}, \mathrm{S})_{2}$ & 11 (vivianite) & 20 (vivianite) & -0.3 & 2.8 \\
\hline
\end{tabular}

${ }^{\text {a }}$ Measured on the maximum of the 4 point smoothed first derivative of the XANES spectrum

b HAO, hydrous aluminum oxide; HFO, hydrous ferric oxide. See text for details.

${ }^{\mathrm{c}}$ Sum of squares of the residuals. 

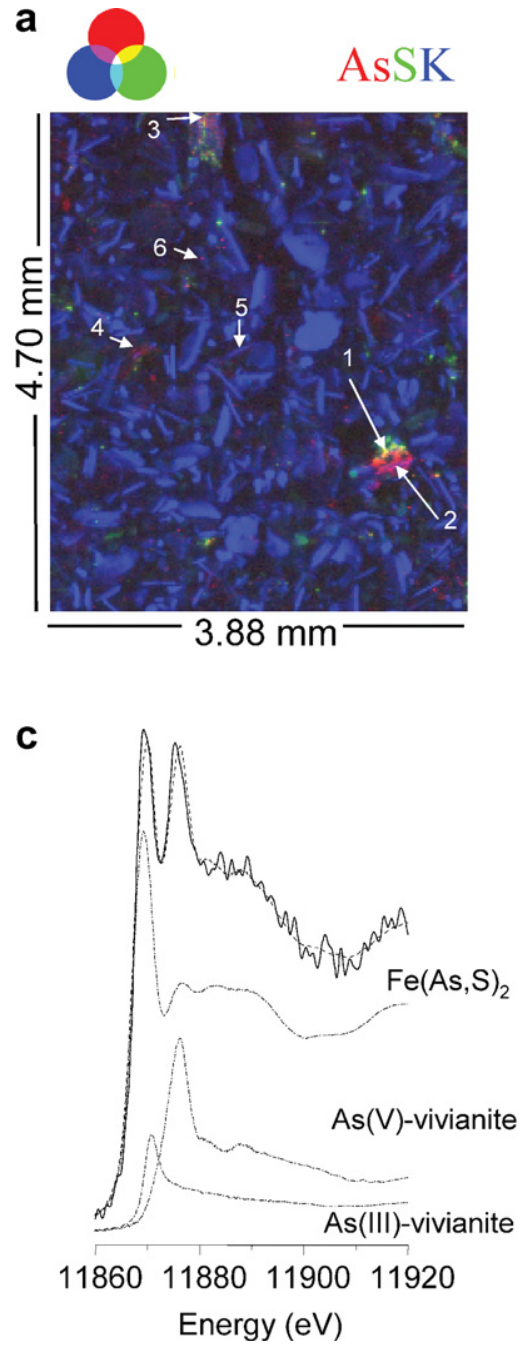

b

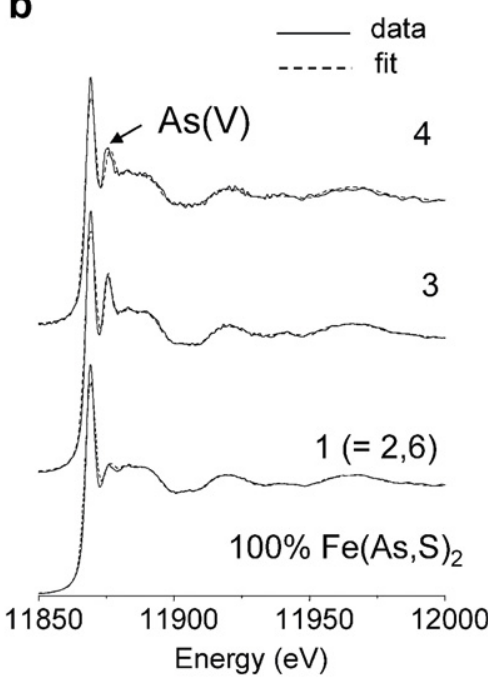

d

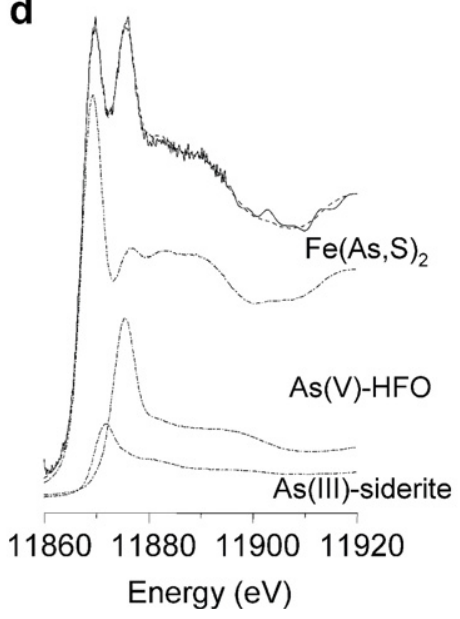

Fig. 7. MicroXAFS results of Srirampur sample $(326.5 \mathrm{~m})$. (a) False color image illustrating grains with high arsenic and sulfur contents. (b) Extended XANES spectra (solid lines) of spots 1, 3, and 4 and least-squares fits (dotted lines) show most arsenic is in pyrite. (c) XANES spectrum of spot 5 (solid line), corresponding least squares fit (heavy dotted line) and fit deconvolution (lighter, labeled dotted lines). Note the similarity in the relative proportion of the arsenian pyrite peak to the arsenate+arsenite peak in this microXANES spectrum to that of (d) the bulk spectrum of the corresponding depth interval.

microXANES spectra were siderite and vivianite; only two of the 12 spots examined at the 39 and $326 \mathrm{~m}$ depth intervals employed HFO in a fit (as an arsenite-HFO coprecipitate; see EA Appendix 1). This is in marked contrast to the bulk XANES fits, where HAO and HFO model compounds provided the best fit in the majority of analyses (the only exceptions are the 326 and 355 depth intervals, in which arsenite coprecipitated with siderite is the preferred arsenite model). However, due to the high noise content of the bulk XANES spectra, it is impossible to assess whether the use of a different species in the least squares fits to these spectra is significant. There was no consistency or trend in the particular arsenite and arsenate model compounds providing the best fits to the extended microXANES spectra. The intrinsic limitations of the information provided in the arsenite and arsenate XANES spectra is certainly a factor, but the non-representative nature of this type of analysis might also give rise to differences between fits to bulk and microXANES spectra.

\subsection{Sulfide textures and morphology}

Polished grain mounts examined with the SEM contain authigenic and sparse detrital sulfide mineral grains. The distinction between authigenic and detrital origin was based on grain morphology. Grains with broken and/or rounded edges were classified as detrital; although some abrasion may have occurred during drilling and handling of the samples. Framboids and euhedral forms were classified as authigenic. Although transport of framboidal forms has been observed (Hossain, 1975; Damke et al., 1999), their transport in Bangladesh likely represents local reworking 
rather than distant transport because pyrite will not survive weathering processes in the wet and oxidizing environment of the Bengal region (Nickson et al., 2000).

Pyrite, and trace amounts of $\mathrm{Zn}-\mathrm{Cu}$-rich pyrite, pyrrhotite, sphalerite, and chalcopyrite were detected during the SEM examination. Arsenopyrite and other arsenic-containing minerals, such as orpiment and realgar, proposed by Das et al. (1996) and Chowdhury et al. (1999) were not detected, but XAFS spectroscopy suggests that orpiment may be present. No authigenic pyrite was detected in the river sediment, although rare detrital grains, $10-20 \mu \mathrm{m}$ in diameter are present. Authigenic pyrite, both framboidal and massive, is abundant in gray samples, especially in those collected from depths greater than $50 \mathrm{~m}$. Pyrite intergrowths with biotite and chlorite were common in the gray sediment, but were not observed in the river sands, in shallow unsaturated sediments, or within $\mathrm{Fe}$ deficient micas.

More than $90 \%$ of pyrite grains analyzed by EPMA are classified as authigenic using the guidelines described above. Atomic ratios of iron and sulfur calculated from electron probe analyses (Table EA-2) and X-ray diffraction confirm the iron sulfide phase to be pyrite as opposed to marcasite, mackinawite, or greigite. Although Akai et al. (2004) report greigite at $\sim 49 \mathrm{~m}$ in western Bangladesh, it was not detected in this study. Authigenic FeS was observed only in a shallow sample collected at Srirampur where it formed a $\sim 7 \mu \mathrm{m}$ massive rim on framboidal pyrite.

Framboid diameters range from 2 to $50 \mu \mathrm{m}$ with an average diameter of $\sim 10 \mu \mathrm{m}$. Crystallites, either spherical or octahedral, comprising individual framboids are of uniform size and shape and average $1 \mu \mathrm{m}$ in diameter. Framboidal pyrite was subdivided into open and filled categories dependent on how readily individual crystallites were distinguished. Open framboids are composed of isolated (non-touching) crystallites whose size and shape could easily be determined (Fig. 8a). Filled framboids contain intergrown crystallites or voids between crystallites have been infilled with massive pyrite. Most framboids, regardless of being open or filled, are spherical. The few irregularly shaped framboids were distorted by compaction or by the space available for growth. Some framboids have been overgrown with massive or octahedral pyrite, particularly those in close vicinity to organic matter (Fig. 8b and c). Massive pyrite is divided into octahedral, cubic, and irregular forms. Octahedral (and cubic) crystals were found as overgrowths on framboids and as clusters of octahedra located near organic matter (Fig. 8d). The size of the octahedra ranges from $2 \mu \mathrm{m}$ to over $50 \mu \mathrm{m}$. The irregular forms have features that suggest they grew in place because the delicate surface structures would not survive transport. The irregular forms range from $10 \mu \mathrm{m}$ to over $100 \mu \mathrm{m}$. The most notable occurrence of an irregular form was found as massive pyrite replacing chloritized biotite in SH2-37 (Fig. 8e). Progressive replacement of biotite by authigenic pyrite was noted in several gray samples. Small framboids apparently nucleate well within mica plates (Fig. 8f), progressively grow resulting in 'kinking' of the plates, and eventually become a massive replacement of the entire grain (Fig. 8e).
Massive and framboidal pyrite in the shallow sediment are similar to those in the deep sediment, with the exception that no massive forms were found in the shallowest samples in either borehole or the samples from the surface excavations (SP-5-1 and SP41-1). While morphologies were not restricted to specific depths, a few textural variations with depth were noted. The number of filled framboids increases with depth relative to open framboids. The size of the massive grains increases with depth although the number of samples is limited. Framboid and crystallite size and the proportion of framboidal to massive grains do not vary systematically with depth.

\subsection{Arsenic content of pyrite}

Arsenic content of pyrite grains as determined by electron microprobe is summarized in Tables 3 and EA-2. The inverse correlation of arsenic and sulfur is consistent with arsenic substitution for sulfur (Fig. 9). Observed scatter in arsenic atom percent at values less than 0.05 is attributed to higher error at low concentrations. A linear least squares fit for arsenic and sulfur for the massive varieties at Srirampur has an $r^{2}$ value of 0.675 . In contrast, arsenic does not systematically substitute for sulfur in framboids based on the arsenic-sulfur $r^{2}$ value of 0.035. Similar As$\mathrm{S}$ relations were detected in the Rajoir borehole.

The median arsenic content of the framboids is $1500 \mathrm{ppm}$ with an observed range from $<300$ to over $11,000 \mathrm{ppm}$. Higher arsenic contents in framboids are associated with those found near organic matter and in micaand clay-rich samples. Framboids within a sample have a range of arsenic contents, however multiple spot analyses within a framboid yielded similar arsenic contents. There is no systematic change in the arsenic content of framboids with depth, nor is there systematic difference in arsenic content in closed relative to open framboids (Table 3 ).

The median arsenic content of the massive pyrite is $3200 \mathrm{ppm}$ with an observed range from $<300$ to $13,000 \mathrm{ppm}$ arsenic. Massive overgrowths on arsenic-poor framboids generally contain between 2000 and 8000 ppm arsenic; some overgrowths contain as much as $10,000 \mathrm{ppm}$ arsenic. The massive varieties have higher arsenic contents than framboids (Fig. 10). Oscillatory arsenic zoning, with a range from $<300$ to over $13,000 \mathrm{ppm}$ As, was observed in some of the octahedra, particularly those associated with organic matter (Fig. 8d). No systematic differences in the arsenic contents of octahedral, cubic, and irregular morphologies were observed.

The arsenic contents of pyrite from the Bengal basin sediments overlap with arsenic in pyrite preserved in other sedimentary units. Arsenic contents in natural pyrites range from 20 to $300 \mathrm{ppm}$ in marine sediment, up to $\sim 100 \mathrm{ppm}$ in brackish settings, $<50 \mathrm{ppm}$ in lacustrine settings, and as much as 10,000 ppm in coal (Schoonen, 2004, Table 2). Pyrites analyzed from the Black Warrior coal basin in Alabama contain from $3000 \mathrm{ppm}$ to 4.5 weight percent arsenic (Goldhaber et al., 2003) and Kolker et al. (2003) report values up to 7 weight percent arsenic in authigenic pyrite in sandy glacial aquifers in southeastern Michigan. Although some of these occurrences are the product of diagenesis 

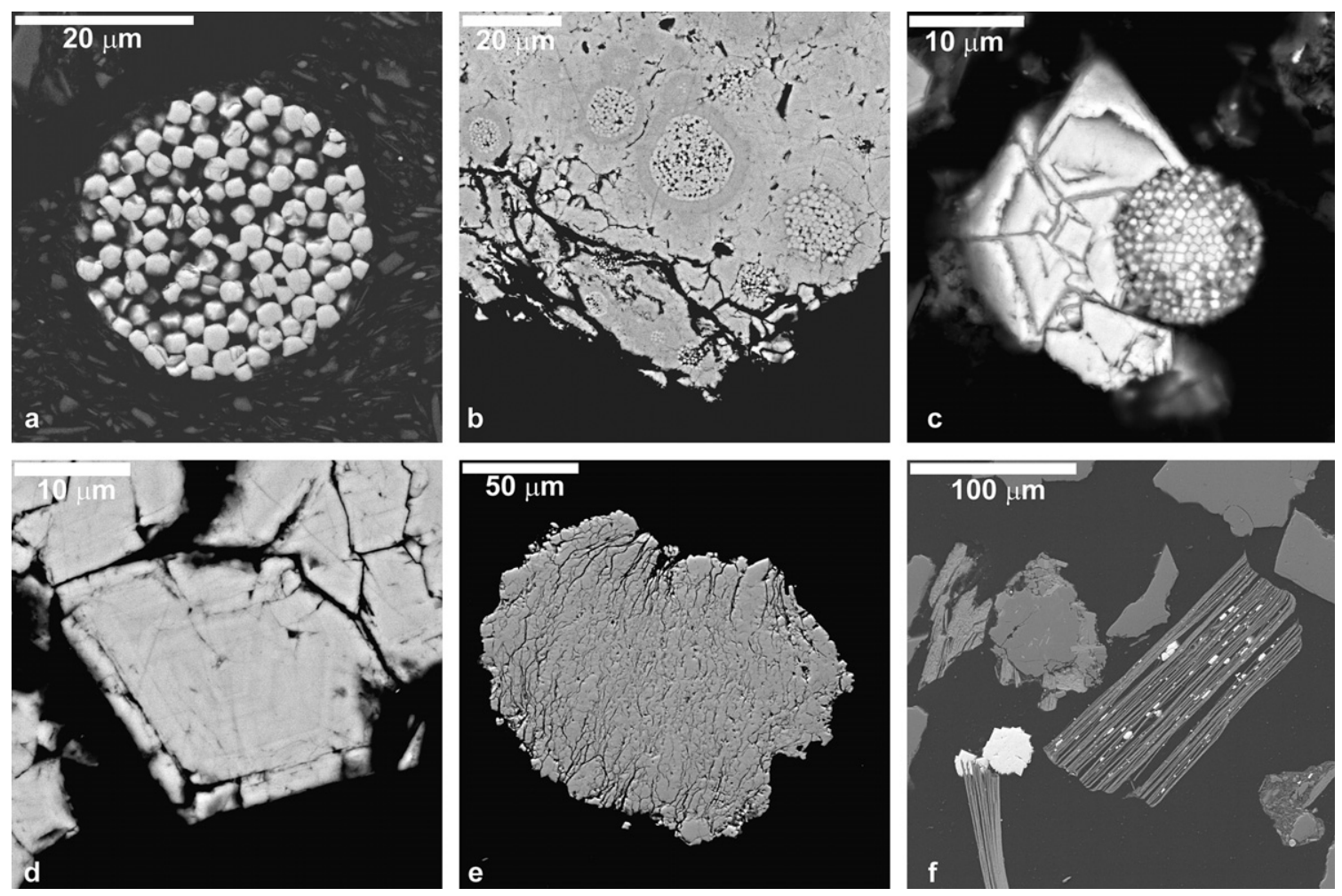

Fig. 8. Backscattered electron images of pyrite forms in Bangladesh sediment. (a) Open framboid texture (Rajoir $99 \mathrm{~m}$ ). (b) Massive overgrown framboid texture (Rajoir $167 \mathrm{~m}$ ). (c) Octahedral overgrowths on framboidal pyrite (Srirampur $355 \mathrm{~m}$ ). (d) Octahedral pyrite (Srirampur $355 \mathrm{~m}$ ). Brighter zones indicate areas with greater arsenic contents. (e) Massive pyrite formed by replacement of a biotite grain. Residual biotite was detected within the grain (Rajoir $450 \mathrm{~m}$ ). (f) Pyrite nucleating between biotite layers (Srirampur $1071 \mathrm{~m}$ ).

Table 3

Arsenic contents (ppm) of framboidal and massive morphologies from the depth intervals sampled

\begin{tabular}{|c|c|c|c|c|c|c|c|c|c|c|}
\hline \multirow[t]{2}{*}{ Locale } & \multirow[t]{2}{*}{ Sample } & \multirow[t]{2}{*}{ Depth (m) } & \multicolumn{4}{|c|}{ Framboid } & \multicolumn{4}{|c|}{ Massive } \\
\hline & & & Min & $\operatorname{Max}$ & Median & $n$ & Min & $\operatorname{Max}$ & Median & $n$ \\
\hline Rajoir & SP41-1 & 2.5 & $<300$ & 6020 & 2670 & 4 & np & np & $\mathrm{np}$ & 0 \\
\hline Rajoir & SH2-09 & 99 & 573 & 11030 & 4750 & 8 & 790 & 4640 & 2040 & 25 \\
\hline Rajoir & SH2-15 & 167 & $<300$ & 6240 & 1210 & 24 & 300 & 11500 & 7230 & 14 \\
\hline Rajoir & SH2-37 & 450 & 350 & 8180 & 1600 & 5 & 320 & 12600 & 3570 & 14 \\
\hline Srirampur & SP-5-1 & 3.2 & 2700 & 9450 & 3570 & 6 & $\mathrm{np}$ & $\mathrm{np}$ & $\mathrm{np}$ & 0 \\
\hline Srirampur & SH1-01 & 22.6 & $<300$ & 7360 & 1580 & 10 & 3600 & 6530 & 5750 & 4 \\
\hline Srirampur & SH1-12 & 114 & $<300$ & 4220 & 1300 & 17 & $<300$ & 6790 & 1270 & 5 \\
\hline Srirampur & SH1-37 & 355 & 577 & 6750 & 1930 & 7 & 470 & 5660 & 3810 & 7 \\
\hline
\end{tabular}

Min, minimum; Max, maximum; $n$, number of analyses; $\mathrm{np}$, not present.

and fluid migration $\left(T>25^{\circ} \mathrm{C}\right)$, the importance of incorporating arsenic into pyrite is evident.

\section{DISCUSSION}

\subsection{Arsenic in the Bengal Basin sediment}

Arsenic speciation within the Bengal Basin sediment varies with depth. Breit et al. (2004) recognized that arsenic in shallow sediment above the water table is present as arsenate bound to iron oxides while the immediately subjacent gray, water-saturated sediment contains mainly As(III) bound to several phases and arsenic in pyrite. With increas- ing depth, arsenite and arsenate variably contained in siderite, vivianite, and sorbed to HFO and HAO-type phases persist with decreasing abundance (Table 2 and Fig. 4). Ferric oxyhydroxides are of minor importance as an arsenic residence below $\sim 100 \mathrm{~m}$. Pyrite accounts for more than $70 \%$ of the arsenic in deep sediment (Table 2, Figs. 3 and 4). Polizzotto et al. (2005) similarly recognized that $60 \%$ of the total arsenic in the Holocene aquifer sediments (5$60 \mathrm{~m}$ ) in central Bangladesh is incorporated in (unidentified) arsenic-bearing sulfides with the remaining portion in arsenate- and arsenite-containing phases. Although empirically recognized as important, details of arsenic incorporation into pyrite has been described only generally. 

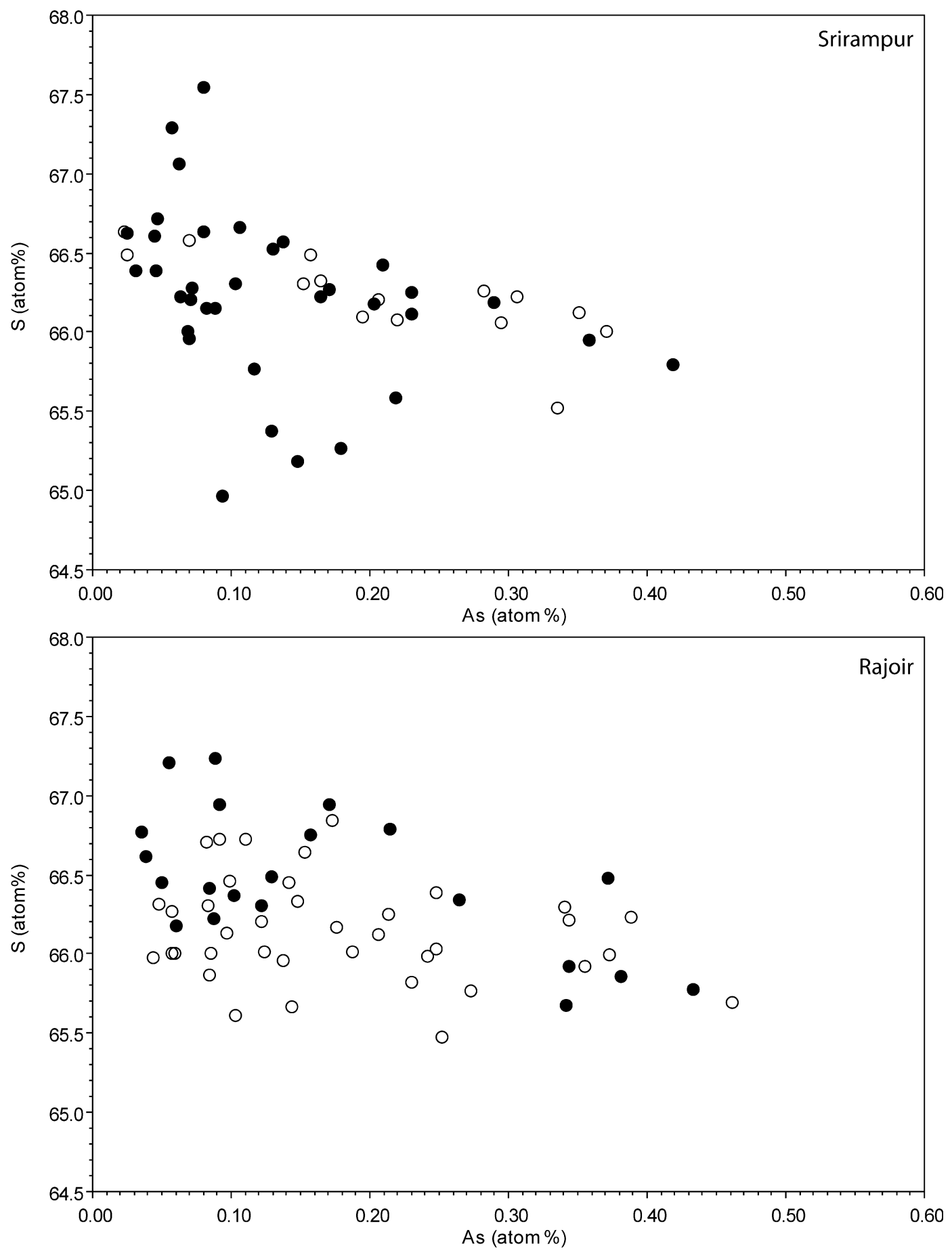

Fig. 9. Sulfur versus arsenic concentrations in pyrite measured by electron probe for Rajoir (bottom) and Srirampur (top) samples. The extent of arsenic substitution for sulfur is consistent with bulk sediment composition (Fig. 3). (closed symbols, framboids; open symbols, massive).

\subsection{Assimilation of arsenic into pyrite}

The incorporation of arsenic into pyrite is affected by arsenic specification and processes of crystal growth. Previous XAS studies suggest that when arsenite is adsorbed to pyrite, an "arsenopyrite-like" surface precipitate is formed (Bostick and Fendorf, 2003), whereas when arsenic is incorporated into growing pyrite (under hydrothermal condi- tions, at least) it substitutes for sulfur in crystallographic sites (Savage et al., 2000). Since arsenopyrite and arsenian pyrite can be readily distinguished (see Appendix AE-1), our findings indicate that the majority of pyrite-associated arsenic was incorporated into pyrite concurrent with its formation. Inferred substitution of arsenic for sulfur is also evident in the microprobe data (Fig. 9). However, since dissolved arsenite is present in ground water in contact with 


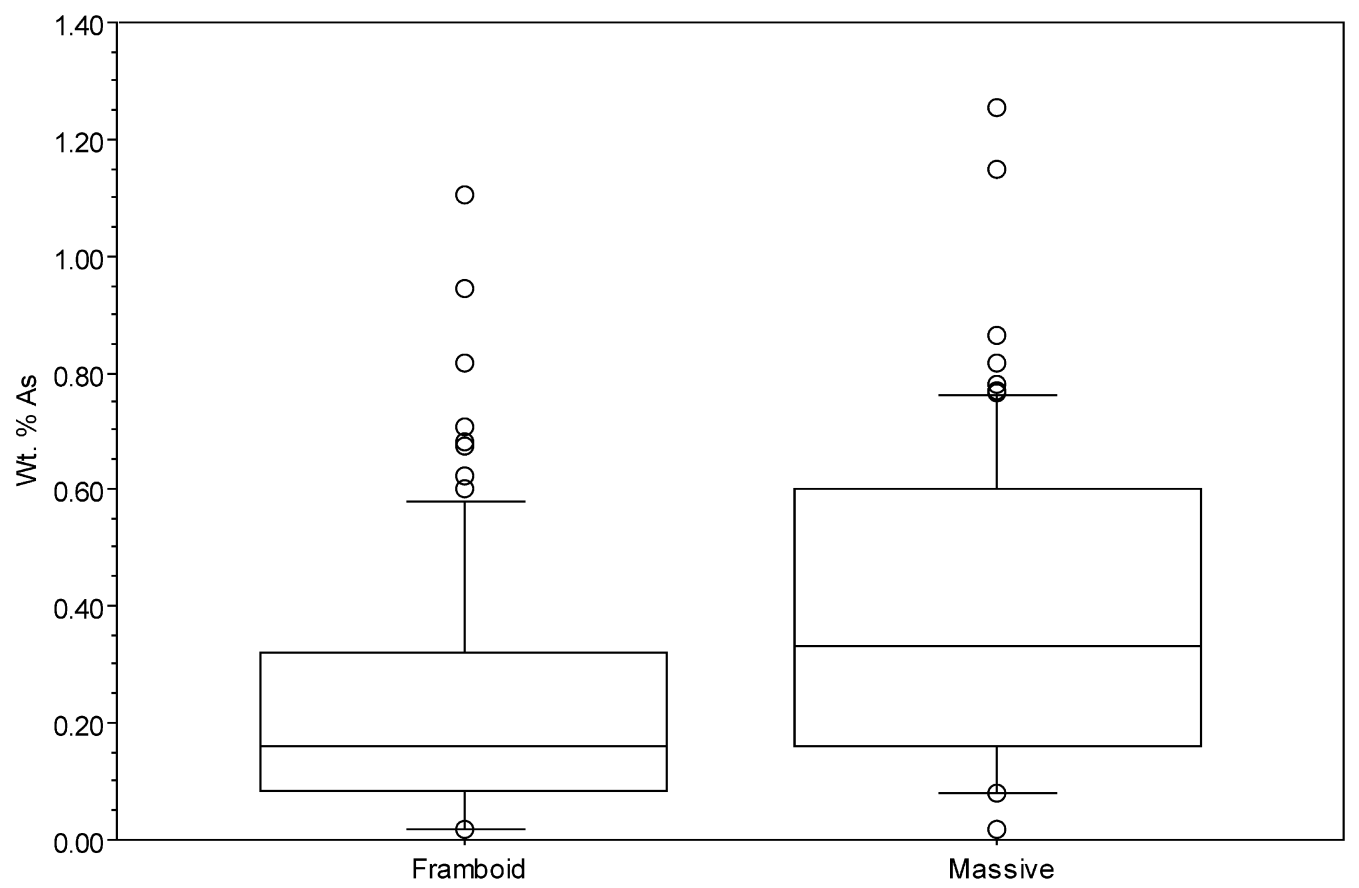

Fig. 10. Box plot comparing arsenic concentrations measured by EPMA between massive and $(n, 66)$ and framboidal pyrite $(n, 78)$ from both boreholes.

these pyrite-rich sediments, it is possible that the arsenian pyrite is coated with arsenopyrite-like surface precipitates. The quality of the microXANES spectral fits using arsenian pyrite alone (fit totals near 100\% for most samples) suggest that an arsenopyrite-like surface precipitate, if present, is of minor abundance.

The presence of arsenian pyrite and possibly orpiment are consistent with calculated thermodynamic stabilities. Arsenic phases predicted to be stable in contact with water compositions typical of those recovered from gray Holocene sediment (BGS and DPHE, 2001) were evaluated with Geochemist's Workbench. The thermo.com.v8.v6.full database was modified with arsenic thermodynamic data of Nordstrom and Archer (2003) and Pokrovski et al. (2002); thioarsenite species were suppressed based on the abundance of reactive iron in the sediment (Wilkin et al., 2003). The stability of arsenian pyrite was approximated by the stabilities of arsenopyrite and pyrite because thermodynamic data for arsenian pyrite is not available. In addition, pyrite is kinetically favored to form relative to direct precipitation of FeAsS (Fleet et al., 1989) as reflected in many of the octahedral pyrite grains that have As zoning (Fig. 8d). As expected, ground waters are saturated with arsenopyrite and pyrite at the circumneutral $\mathrm{pH}$ of most Bangladesh ground water. Orpiment dominance is predicted in water with $\mathrm{pH}<6$ and dissolved iron content less than $0.5 \mathrm{mg} \mathrm{L}^{-1}$. These conditions are likely in carbonaceous sediments that have elevated $\mathrm{pCO}_{2}$ and lack clastic iron input such as the peaty sediment near Rajoir.

The concentration of arsenic in pyrite is the product of growth rate, the abundance of arsenic in solution, and the dissolved As:S ratio (Bostick and Fendorf, 2003; Fleet et al., 1989). Akai et al. (2004), Kirk et al. (2004), and
O'Day et al. (2004) have proposed that arsenic incorporation into iron sulfide is dependent on the rate of sulfur supplied by bacterial sulfate reduction. Arsenic incorporation in pyrite is expected to increase in response to lowered sulfur activities found in Bengal Basin sediment deeper than $20 \mathrm{~m}$ (Fig. 11). As sulfur is depleted, pore waters cease to be supersaturated and pyrite growth becomes more prevalent than nucleation, which results in euhedral morphologies (Wang and Morse, 1996; Grimes et al., 2002; Sawlowicz, 2000). Under conditions of slower growth, greater content of arsenic in the pyrite is likely based on results of Bostick and Fendorf (2003) who found that arsenic sorption to pyrite increased with longer exposure to arsenicrich solutions. The massive pyrite common in deeper samples generally contains more arsenic than associated framboids (Fig. 10), an observation that is not unique to the pyrite in Bengal Basin sediment (Goldhaber et al., 2003; Kolker et al., 2003).

Framboidal pyrite is favored in the upper $20 \mathrm{~m}$ of Bengal Basin borehole sediment because of rapid precipitation rates in settings with adequate supplies of both $\mathrm{Fe}$ and S (Wang and Morse, 1996; Grimes et al., 2002). Consistent with this interpretation framboids were the only morphology observed in the gray sediment from excavations and the borehole samples from $<22 \mathrm{~m}$. The uniform content of arsenic within an individual framboid suggests the crystallites formed under similar pore-water compositions that sustained nucleation and growth (Matijevic, 1996; Wilkin and Barnes, 1997). The variation in arsenic content among framboids within a sample is attributed to heterogeneity of the sediment or microniches of varying saturation states (Grimes et al., 2002; Diehl et al., 2005; Sawlowicz, 2000). 


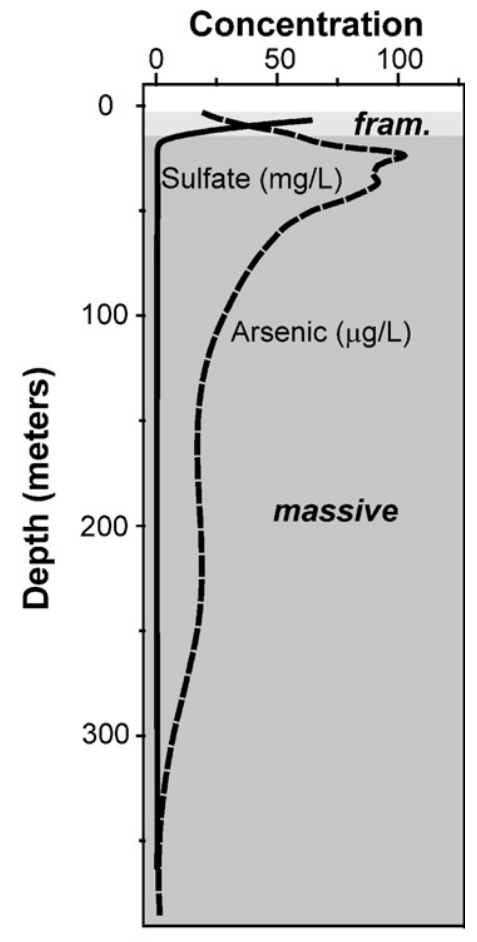

Fig. 11. Probable depth intervals for the formation of framboidal (fram.) and massive pyrite based on petrographic observations. Concentration curves for sulfate and arsenic are best fit Loess lines calculated using the data of BGS and DPHE (2001). Plotted curves based on data from wells south of 23.5 north latitude and between 89.5 and 91.8 degrees east longitude $(n=97)$.

Although useful, these findings do not shed light on the many unanswered questions regarding the mechanism and timing of low temperature pyrite formation (e.g., Butler and Rickard, 2000). However, some information is gleaned from the bulk chemical data and textural observations of Bengal Basin pyrite. The pyrite most likely forms via at least two mechanisms. The first is conversion of AVS to pyrite as indicated by the AVS to pyrite ratio which decreases with depth (Fig. 5). The second possible method of pyrite formation is through heterogeneous nucleation on surfaces without amorphous FeS precursors. This is evident from the formation of pyrite framboids within the sheets of iron-rich micas which eventually grow to replace the entire mica grain (Fig. 8e). Rickard et al. (2007) were able to nucleate pyrite framboids within the cell walls of celery via a two step process whereby $\mathrm{Fe}(\mathrm{II})$ diffusion and subsequent $\mathrm{S}(-\mathrm{II})$ penetrate and react within the cell walls. Once formed, the pyrite seeds act as nucleation sites to facilitate further pyrite growth (Schoonen, 2004; Rickard et al., 2007).

\subsection{Sulfur supply}

Multiple sources of sulfur are necessary to reasonably explain the isotopic composition and abundance of sulfur forms in the sediment. Natural sources of sulfate available for reduction within the Bengal Basin sediment include oxidation of detrital sulfides, atmospheric deposition, river water, and sea water. Detailed evaluation of these sources is described in the EA Appendix 2 and summarized in Fig. 12. The median amount of sulfur in the sediment (Table 1) exceeds the amount that can be supplied by atmospheric deposition or redistribution of sulfur in existing surficial sediment based on likely rates of sediment accumulation $\left(0.1-1 \mathrm{~cm} \mathrm{a}^{-1}\right)$. Therefore, riverine and seawater inputs are required. To refine this conclusion, three groups of sediment samples were evaluated using the results of the sulfur isotope and sulfur speciation analyses (Fig. 5). The first group has $\delta^{34} \mathrm{~S}$ values between +6 and $-6 \%$ and pyritic sulfur $\left(\mathrm{S}_{\mathrm{PY}}\right)$ concentration between 60 and $1000 \mathrm{ppm}$. These values are consistent with a riverine sulfur supply that would increase the sediment sulfur content to between 100 and $1300 \mathrm{ppm} \mathrm{S}$ depending on the rate of sediment deposition. The second population consists of 7 samples with $\delta^{34} \mathrm{~S}_{\mathrm{PY}}$ values from $8 \%$ to $32 \%$ and $\mathrm{S}_{\mathrm{PY}}$ contents ranging from 40 to $1100 \mathrm{ppm}$. Although these results can be explained by advective transport of partially reduced riverine sulfate to a site of further reduction, a limited supply of seawater sulfate offers a simpler explanation. A seawater source is particularly favored to explain a sample from Srirampur at $114.5 \mathrm{~m}$ depth that contains $1090 \mathrm{ppm} \mathrm{S}_{\mathrm{PY}}$ with a $\delta^{34} \mathrm{~S}_{\mathrm{PY}}$ of $29.2 \%$. The third population includes 3 samples with $>1500 \mathrm{ppm} \mathrm{S}_{\mathrm{PY}}$ and $\delta^{34} \mathrm{~S}$ values $<-9 \%$, which is

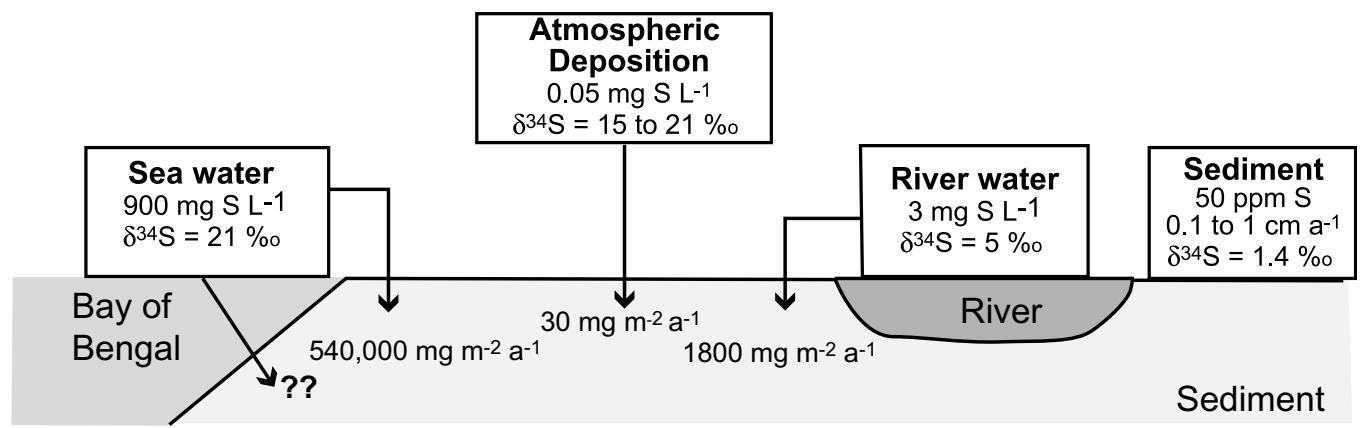

Fig. 12. Generalized diagram of sulfur fluxes from natural sources into the subaerial sediment of the Bengal Basin. Fluxes estimated from the concentrations of sulfur as described in the electronic annex and assuming a $0.6 \mathrm{~m} \mathrm{a}^{-1}$ annual recharge (BGS and DPHE, 2001). Influence of sea water likely is limited to within $100 \mathrm{~km}$ of the coastline. Contributions of river water are restricted to flood plains marginal to the rivers. 
explained by a sulfate source of high concentration that was only partially reduced. The high abundance of sulfur and low $\delta^{34} S_{P Y}$ values render sea water the most likely source of sulfate and that the amount of sulfate exceeded the reducing capacity of the sediment.

The two shallowest samples from the Rajoir borehole are examples of populations 2 and 3 . Sediment at $11 \mathrm{~m}$ depth contains the greatest amount of measured $\mathrm{S}_{\mathrm{PY}}$ (1 wt. \%). This pyrite has a $\delta^{34} \mathrm{~S}$ value of $-9.1 \%$ and is associated with $+35 \%$ sulfate. In contrast, a sample at $22 \mathrm{~m}$ depth contains $\mathrm{S}_{\mathrm{PY}}$ of $350 \mathrm{ppm}$ and a $\delta^{34} \mathrm{~S}_{\mathrm{PY}}$ of $+33 \%$. The simplest explanation for this distribution is that sea water interacted directly with the carbonaceous sediment at $11 \mathrm{~m}$ and that residual, isotopically evolved sulfate was transported in ground water downward through the sediment and was further reduced to form pyrite in the sediment at $22 \mathrm{~m}$. Exposure of sediment in this depth range to sea water is consistent with the estimated coastline position near Rajoir 6-3 ka BP (Goodbred and Kuehl, 2000).

The difference between $\delta^{34} \mathrm{~S}_{\mathrm{AVs}}$ and $\delta^{34} \mathrm{~S}_{\mathrm{PY}}$ in most sediment samples is positive or close to zero (Fig. 5d). Positive values are attributed to initial formation of ${ }^{34} \mathrm{~S}$ depleted pyrite and subsequent formation of AVS from the ${ }^{34} \mathrm{~S}$ enriched reservoir. Samples in the upper $50 \mathrm{~m}$ of both boreholes have this characteristic. In contrast, samples in the vicinity of $200-300 \mathrm{~m}$ depth at Srirampur have lower $\delta^{34} \mathrm{~S}_{\mathrm{AvS}}$ values which imply addition of sulfate in ground water subsequent to formation of most pyrite in those samples. Perhaps sea water intrusion affected this interval after much of the pyrite had formed.

The sulfur isotope composition of dissolved sulfate $\left(\delta^{34} \mathrm{~S}_{\mathrm{SO} \text {-D }}\right)$ in Bangladesh ground water further supports multiple sulfate sources. $\delta^{34} \mathrm{~S}_{\mathrm{SO} 4-\mathrm{D}}$ determined by BGS and DPHE (2001) and Zheng et al. (2004) ranges from $-0.9 \%$ to $53 \%$. $\delta^{34} \mathrm{~S}_{\mathrm{SO}-\mathrm{D}}$ values $<5 \%$ are attributed to oxidation of authigenic sulfide as is likely to explain the acid-soluble sulfate deep $(326.5 \mathrm{~m})$ in the Srirampur borehole $(-13.4 \%)$. Although the data of BGS and DPHE (2001) and Zheng et al. (2004) show that $\delta^{34}$ S SO4-D $_{\text {gener- }}$ ally increases with decreasing concentration as expected for bacterial sulfate reduction (Lyons, 1997; Schoonen, 2004; Zheng et al., 2004), the large range of $0-26 \%$ measured in a narrow sulfate concentration range (10-20 mg L $\mathrm{L}^{-1}$ ) is greater than expected for any single source outlined above.

The markedly low As/S ratios in the sediment (Fig. 3) between approximately 20 and $50 \mathrm{~m}$ at Srirampur and to a lesser degree at Rajoir are considered a direct reflection of depositional conditions. The brown sediment at $50 \mathrm{~m}$ depth marks the position of the Holocene-Pleistocene unconformity in the Srirampur borehole. Goodbred and Kuehl (2000) and Acharyya (2005) proposed that following the unconformity, sea level rose as fast as $1-2 \mathrm{~cm} \mathrm{yr}^{-1}$ from 12 to $6 \mathrm{ka}$ BP resulting in rapid aggradation of sediment. Rapid sediment deposition between 50 and $20 \mathrm{~m}$ depth effectively diluted the sulfur fluxes, particularly because sea water input was unlikely. Applying the riverine and atmospheric fluxes to sediment accumulating at $1 \mathrm{~cm} \mathrm{yr}^{-1}$ would result in sediment with concentrations of sulfur less than $0.01 \mathrm{wt} . \%$ while arsenic provided in ferric oxyhydrox- ide grain coatings likely remained constant. From 6 to about $3 \mathrm{ka}$ BP the aggradation of sediment reduced sharply and further declined after 3000 years BP (Goodbred and Kuehl, 2000). Deposition at slower rates near $0.1 \mathrm{~cm} \mathrm{yr}^{-1}$ is likely to produce sulfur concentrations near $0.1 \mathrm{wt} . \%$ with riverine input, which is similar to the value measured in some of the slowly deposited sediment in the upper $20 \mathrm{~m}$. The shallowest Rajoir sediment is marked by very low As/S ratios which is attributed to a large influx of sulfur from sea water. The relative lack of sulfur in sediment between 50 and approximately $100 \mathrm{~m}$ could be related to circulation of dilute ground water in response to the position of sea level $120 \mathrm{~m}$ below the current mean sea level at the end of the Pleistocene (Ravenscroft and McArthur, 2004). Alternatively, the lower sulfur content could reflect depositional conditions during the Pleistocene, which limited sulfur content much as it was limited in the lower Holocene. Full interpretation of the sediment at $>50 \mathrm{~m}$ depth requires a more complete description of depositional environments and rates of accumulation.

\section{SUMMARY}

Pyrite has a major role in the arsenic geochemistry in the sediment of the Bengal Basin. Arsenic released during weathering of rocks and sediment from the Himalayas adds to the arsenic load of modern sediments in the form of ferric oxides that coat grain surfaces. Reducing conditions in the subsurface dissolve ferric oxides and release contained arsenic. In the presence of adequate sulfate, the dissolved arsenic is partitioned into pyrite. Framboids form near the top of the saturated zone while massive textures form deeper in the sediment in response to slower growth attributed to limited sulfate. Higher dissolved arsenic:sulfur ratios are likely in the deeper sediment which favors incorporation of proportionally greater amounts of arsenic into the massive pyrite. Pyrite abundance in deep sediment and active sulfate reduction in very shallow sediment $(<20 \mathrm{~m})$ could account for the generally low concentration of arsenic in ground water from those depth intervals.

\section{ACKNOWLEDGMENTS}

This research was carried out under contract with the United States State Department and funding support from USAID. The authors thank Cyrus Berry, Dave Siems, Tammy Hannah, Zoe Ann Brown, Rhonda Driscoll, Paul Briggs and David Fey for the chemical analyses. Michele Tuttle, Sharon Diehl, Robert Zielinski, Alex Van Geen and two anonymous reviewers who offered insightful comments that greatly improved the clarity of the manuscript. The dedicated drilling crews of the Geological Survey of Bangladesh and Bangladesh Water Development Board made borehole sampling possible. The Stanford Synchrotron Radiation Laboratory is a national user facility operated by Stanford University on behalf of the U.S. Department of Energy, Office of Basic Energy Sciences. The SSRL Structural Molecular Biology Program is supported by the Department of Energy, Office of Biological and Environmental Research, and by the National Institutes of Health, National Center for Research Resources, Biomedical Technology Program. The A.L.S. is supported by the Director, Office of Energy Research, Office of Basic Energy Sciences, Materials Sciences Divi- 
sion of the U.S. Department of Energy, under Contract No. DEAC02-05CH11231.

\section{APPENDIX A. ELECTRONIC ANNEX}

Supplementary data associated with this article can be found, in the online version, at doi:10.1016/j.gca. 2007.03.022.

\section{REFERENCES}

Acharyya S. K. (2002) Arsenic contamination in groundwater affecting major parts of southern West Bengal and parts of western Chhattisgarh: source and mobilization process. Curr. Sci. 82, 740-744.

Acharyya S. K. (2005) Arsenic levels in groundwater from quaternary alluvium in the Ganga Plain and the Bengal Basin, Indian Subcontinent: insights into Influence of stratigraphy. Gondwana Res. 8, 55-66.

Acharyya S. K., Lahiri S., Raymahashay B. C., and Bhowmik A. (2000) Arsenic toxicity of groundwater in parts of the Bengal basin in India and Bangladesh: the role of quaternary stratigraphy and Holocene sea-level fluctuation. Environ. Geol. 39, $1127-1137$.

Akai J., Izumi K., Fukuhara H., Masuda H., Nakano S., Yoshimura Ohfuji H., Anawar H. M., and Akai K. (2004) Mineralogical and geomicrobiological investigations on groundwater arsenic enrichment in Bangladesh. Appl. Geochem. 19, 215-230.

Berg M., Tran H. C., Nguyen T. C., Pham H. V., Schertenleib R., and Giger W. (2001) Arsenic contamination of groundwater and drinking water in Vietnam: a human health threat. Envrion. Sci. Techol. 35, 2621-2626.

BGS and DPHE (2001). In Arsenic Contamination of groundwater in Bangladesh. BGS Technical Report WC/00/19 (eds. D. G. Kinniburgh and P. L. Smedley). British Geological Survey, Keyworth.

Bostick B. C., and Fendorf S. (2003) Arsenite sorption on troilite $(\mathrm{FeS})$ and pyrite (FeS2). Geochim. Cosmochim. Acta 67, 909921.

Breit, G. N., Foster, A. L., Perkins, R. B., Yount, J. C., King Trude, Welch, A. H., Whitney, J. W., Uddin, N., Muneem, A. A. and Alam, M. (2004) As-rich Ferric oxyhydroxide enrichments in the shallow subsurface of Bangladesh. In Proceedings of the 11th International Symposium. Water-Rock Interaction (eds. R. B. Wanty and R. R. Seal). WRI-11, Balkema, New York, pp. 1457-1461.

Breit, G. N., Yount, J. C., Uddin, M. N., Muneem, A. A., Lowers, H. A., Driscoll, R. L. and Whitney, J. W. (2006) Compositional data for Bengal delta sediment collected from boreholes at Srirampur, Kachua, Bangladesh. U.S. Geol. Surv. Open-file Report 2006-1222, 58p.(http://pubs.er.usgs.gov/usgspubs/ofr/ ofr20061222)

Breit, G. N. Yount, J. C., Uddin, M. N., Muneem, A. A., Lowers, H. A., Berry, C. J., and Whitney, J. W. (2007) Compositional data for Bengal delta sediment collected from a borehole at Rajoir, Bangladesh. U.S. Geol. Surv. Open-file Report 20071022, 46p. http://pubs.er.usgs.gov/usgspubs/ofr/ofr20071022.

Butler I. B., and Rickard D. (2000) Framboidal pyrite formation via the oxidation of iron (II) monosulfide by hydrogen sulfide. Geochim. Cosmochim. Acta 64, 2665-2672.

Chatterjee A. D., Das D., Mandal B. K., Chowdhury T. R., Samanta G., and Chakraborty D. (1995) Arsenic in groundwater in 6 districts of West Bengal, India - the biggest arsenic calamity in the world. A. Arsenic species in drinking water and urine of affected people. Analyst 120, 643-650.

Chowdhury T. R., Basu G. K., Mandal B. K., Biswas B. K., Samanta G., Chowdhury U. K., Chanda C. R., Lodh D., Lal Roy S., Saha K. C., Roy S., Kabir S., Quamruzzaman Q., and Chakraborti D. (1999) Arsenic poisoning in the Ganges delta. Comment No. 2. Nature 401, 545-546.

Clesceri, L. S., Freenber, A. E. and Eaton, A. D., (Eds.) (1998) 3500-Iron, B. Phenanthroline method in Standard Methods for the Examination of Water and Wastewater, 20th edition. Washington D.C.: American Public Health Association, pp. 3-76-3-78.

Damke H., Henning K. H., Lehmann J., Kasbohm J., and Puff T. (1999) Phase composition of flood sediments of the GermanPolish Odra river immediately after the flood event in 1997. Acta Hydrochim. Hydrobiol. 27, 357-363.

Das D., Samanta G., Manda B. K., Chowdhury T. R., Chanda C. R., Chowdhury P. P., Basu G. K., and Chakraborti D. (1996) Arsenic in groundwater in six districts of West Bengal, India. Environ. Geochem. Health 18, 5-15.

Diehl, S. F., Goldhaber, M. B., Tuttle, M. L. W., Ruppert, L. F., Hatch, J. R., Koenig, A. E. and Lowers, H. A. (2005) Concentration of arsenic, selenium, and other trace elements in pyrite-filled structures in Appalachian coals of Alabama, Kentucky, and West Virginia. In Proceedings of the 22nd International Pittsburg Coal Conference; Coal Chemistry, Geosciences Resources, September 12-15, Pittsburgh, PS, CD ROM, $24 \mathrm{p}$.

Farmer J. G., and Lovell M. A. (1986) Natural enrichment of arsenic in Loch Lomond sediments. Geochim. Cosmochim. Acta 50, 2059-2067.

Fleet M. E., MacLean P. J., and Barbier J. (1989) Oscillatoryzoned As-bearing pyrite from stratabound and stratiform gold deposits: an indicator of ore fluid evolution. Econ. Geol. Monogr. 6, 356-362.

Foster A. L., Brown, Jr., G. E., and Parks G. A. (1998a) X-ray absorption fine structure spectroscopy study of photocatalyzed, heterogeneous As(III) oxidation on kaolin and anatase. Environ. Sci. Technol. 32, 1444-1452.

Foster A. L., Brown, Jr., G. E., Parks G. A., and Tingle T. N. (1998b) Quantitative speciation of arsenic in mine tailings using X-ray absorption spectroscopy. Am. Mineral. 89, 553-568.

Foster, A. L. (1999) Partitioning and transformation of arsenic and selenium in natural and laboratory systems. Ph.D. Thesis, Stanford University.

Foster A. L. (2003) Spectroscopic investigations of arsenic species in solid phases. In Arsenic in Groundwater: Geochemistry and Occurrence (eds. A. H. Welch and K. G. Stollenwerk). Kluwer Academic Publishers, Norwell, $475 \mathrm{p}$.

Goldhaber M. B., Lee R. C., Hatch J. R., Pashin J. C., and Treworgy J. (2003) Role of large scale fluid-flow in subsurface arsenic enrichment. In Arsenic in Groundwater (eds. A. H. Welch and K. G. Stollenwerk). Kluwer Academic Publishers, pp. 127-164.

Goodbred, Jr., S. L., and Kuehl S. A. (2000) The significance of large sediment supply, active tectonism, and eustasy on margin sequence development: late quaternary stratigraphy and evolution of the Ganges-Brahmaputra delta. Sed. Geol. 133, 227-248.

Grimes S. T., Davies K. L., Butler I. B., Brock F., Edwards D., Rickard D., Briggs D. E. G., and Parkes R. J. (2002) Fossil plants from the Eocene London Clay: the use of pyrite textures to determine the mechanism of pyritization. J. Geol. Soc. Lond. 159, 493-501.

Harvey C. F., Swartz C. H., Badruzaman A. B. M., Keon-Blute N., Yu W., Ali M. A., Jay J., Bechie R., Niedan V., Brabander D., 
Oates M. F., Ashfaque K. N., Islam S., Hemond H. F., and Ahmed M. F. (2002) Arsenic mobility and groundwater extraction in Bangladesh. Science 298, 1602-1606.

Heron G., and Christensen T. H. (1995) Impact of sediment-bound iron on redox buffering in a landfill leachate polluted aquifer, (Vejen, Denmark). Environ. Sci. Tech. 29, 187-192.

Hideki Minam, and Yoshihisa Kat (1997) Remobilization of arsenic in sub-oxic sediments from the seafloor of the continental margin. J. Ocean. 53, 553-562.

Horneman A., Van Geen A., Kent D. V., Mathe P. E., Zheng Y., Dhar R. K., O'Connell S., Hoque M. A., Aziz Z., Shamsudduha M., Seddique A. A., and Ahmed K. M. (2004) Decoupling of As and Fe release to Bangladesh groundwater under reducing conditions. Part 1.: Evidence from sediment profiles. Geochem. Cosmochim. Acta 68, 3459-3473.

Hossain A. (1975) The occurrence of polyframboidal pyrite in a beach sand deposit, Cox's Bazaar, Bangladesh. Am. Mineral. 60, 157-158.

Huerta-Diaz M. A., and Morse J. W. (1992) Pyritization of trace metals in anoxic marine sediments. Geochem. Cosmochim. Acta 56, 2681-2702.

Huerta-Diaz M. A., Tessier A., and Carignan R. (1998) Geochemistry of trace metals associated with reduced sulfur in freshwater sediments. Appl. Geochem. 13, 213-233.

Islam F. S., Gault A. G., Boothman C., Polya D. A., Charnock J. M., Chatterjee D., and Lloyd J. (2004) Role of metal-reducing bacteria in arsenic release from Bengal Delta sediments. Nature (London) 430, 68-71.

Islam F. S., Boothman C., Gault A. G., Polya D. A., and Lloyd J. R. (2005) Potential role of the Fe(III)-reducing bacteria Geobacter and Geothrix in controlling arsenic solubility in Bengal delta sediments. Min. Mag. 69, 865-875.

JICA-Japanese International Cooperation Agency (2002) The study on the ground water development of deep aquifers for safe drinking water supply to arsenic affected areas in western Bangladesh: Kokusai Kogyo Co., Ltd, and Mitsui Mineral Development Engineering Co., Ltd.

Kester C. L., Rye R. O., Johnson C. A., Schwartz Ch., and Homes Ch. (2001) On-line sulfur isotope analysis of organic material by direct combustion: preliminary results and potential applications. Isotopes Environ. Health Studies 37, 53-65.

Kirk M. F., Holm T. R., Park J., Jin Q., Sanford R. A., Fouke B. W., and Bethke C. M. (2004) Bacterial sulfate reduction limits natural arsenic contamination in groundwater. Geology 32, 953-956.

Kolker A., Haack S. K., Cannon W. F., Westjohn D. B., Kim M. J., Nriagu J., Woodruff L. G. (2003) Arsenic in southeastern Michigan. In Arsenic in Groundwater (eds. A.H. Welch and K.G. Stollenwerk) Kluwer Academic Publishers, pp. 281-294.

Lyons T. W. (1997) Sulfur isotopic trends and pathways of iron sulfide formation in upper Holocene sediments of the anoxic Black Sea. Geochim. Cosmochim. Acta 61, 3367-3382.

Marcus M. A., MacDowell A. A., Celestre R., Manceau A., Miller T., Padmore H. A., and Sublett R. E. (2004) Beamline 10.3.2 at ALS: a hard X-ray microprobe for environmental and materials sciences. J. Synchrotron Radiat. 11, 239-247.

Masuda H., Yamatani Y., and Okai M. (2005) Transformation of arsenic compounds in modern intertidal sediments of Iriomote Island, Japan. J. Geochem. Expl. 87, 73-81.

Matijevic E. (1996) Internally and externally composite monodispersed colloid particles. In Fine Particles Science and Technology (ed. E. Pelizzetti) Kluwer Academic Publishers Boston, pp. $1-12$.

McArthur J. M., Banerjee D. M., Hudson-Edwards K. A., Mishhra R., Purohit R., Ravenscroft P., Cronin A., Howarth R. J., Chatterjee A., Talukder T., Lowry D., Houghton S., and
Chadha (2004) Natural organic matter in sedimentary basins and its relation to arsenic in anoxic ground water: the example of West Bengal and its worldwide implications. Appl. Geochem. 19, 1255-1293.

Meharg A. A., Scrimgeour C., Hossain S. A., Fuller K., Cruickshank K., Williams P. N., and Kinniburgh D. G. (2006) Codeposition of organic carbon and arsenic in Bengal delta aquifers. Environ. Sci. Technol. 40, 4928-4935.

Moore J. N., Ficklin W. H., and Johns C. (1988) Partitioning of arsenic and metals in reducing sulfidic sediments. Environ. Sci. Technol. 22, 432-437.

Mucci Alfons, Richard L-F., Lucotte M., and Guignard Constanc (2000) The differential geochemical behavior of arsenic and phosphorous in the water column and sediments of the Saguenay Fjord estuary, Canada. Aquat. Geochem. 6, 293-324.

Nickson R. T., McArthur J. M., Ravenscroft P., Burgess W. G., and Ahmed K. M. (2000) Mechanism of arsenic release to groundwater, Bangladesh and West Bengal. Appl. Geochem. 15, 403-413.

Nordstrom D. K., and Archer D. G. (2003) Arsenic thermodynamic data and environmental geochemistry. In Arsenic in Groundwater (eds. A.H. Welch and K.G. Stollenwerk), Kluwer Academic Publishers, pp. 1-26.

O’Day P. A., Vlassopoulos D., Root R., and Rivera N. (2004) The influence of sulfur and iron on dissolved arsenic concentrations in the shallow subsurface under changing redox conditions. Proc. Natl. Acad. Sci. 101, 13703-13708.

Pirrie, D., Beer, A. J. and Camm, G. S. (1999) Early diagenetic sulphide minerals in the Hayle Estuary, Cornwall. In Geoscience in south-west England 9 (ed. B. J. Williams). pp. 325-332.

Pokrovski G. S., Kara Sam, and Roux Jacque (2002) Stability and solubility of arsenopyrite, FeAsS, in crustal fluids. Geochem. Cosmochim. Acta 66, 2361-2378.

Polizzotto M. L., Harvey C. F., Sutton S. R., and Fendorf S. (2005) Processes conducive to the release and transport of arsenic into aquifers of Bangladesh. Proc. Natl. Acad. Sci. 102, 1881918823.

Ravenscroft P., and McArthur J. M. (2004) Mechanism of regional enrichment of groundwater by boron: the examples of Bangladesh and Michigan, USA. Appl. Geochem. 19, 1413-1430.

Ravenscroft P., Burgess W. G., Ahmed K. M., Burren Mellani, and Perrin Jerom (2005) Arsenic in groundwater of the Bengal Basin, Bangladesh: Distribution, field relations, and hydrogeological setting. Hydrogeol. J. 13, 727-751.

Rice C. A., Tuttle M. L., and Reynolds R. L. (1993) The analysis of forms of sulfur in ancient sediments and sedimentary rocks: comments and cautions. Chem. Geol. 107, 83-95.

Rickard D., Grimes S., Butler I., Oldroyd A., and Davies K. L. (2007) Botanical constraints on pyrite formation. Chem. Geol. 236, 228-246.

Saunders J. A., Lee M. K., Uddin A., Mohammad S., Wilkin R. T., Fayek M., and Korte N. E. (2005a) Natural arsenic contamination of Holocene alluvial aquifers by linked tectonic, weathering, and microbial processes. Geochem. Geophys. Geosys. 6(4).

Saunders J. A., Mohammad S., Korte N. E., Lee M.-K., Fayek M., Castle D., and Barnett M. O. (2005b) Groundwater geochemistry, microbiology, and mineralogy of two arsenic-bearing Holocene alluvial aquifers from the USA. Am. Chem. Soc. Symp. Ser. 915, 191-205.

Saunders J. A., Pritchett M. A., and Cook R. B. (1997) Geochemistry of biogenic pyrite and ferromanganese stream coatings: a bacterial connection? Geomicrobiol. J. 14, 203-217.

Savage K. S., Tingle T. N., O'Day P. A., Waychunas G. A., and Bird D. K. (2000) Arsenic speciation in pyrite and secondary 
weathering phases, Mother Lode Gold District, Tuolumne County, California. Appl. Geochem. 15, 1219-1244.

Sawlowicz Z. (2000) Framboids: from their origin to application. Prace Mineralog. Pan (Krakow) (Mineralog. Trans.) 88, 1-80.

Schoonen, M. A. A. (2004) Mechanisms of sedimentary pyrite formation. In Sulfur Biogeochemistry - Past and Present. Geological Society of America Speciation (eds. J. P. Amend, K. J. Edwards and T. W. Lyons). Pap. 379, pp. 117-134.

Slowey A. J., Rytuba J. J., and Brown, Jr., G. E. (2005) Speciation of mercury and mode of transport from Placer gold mine tailings. Environ. Sci. Technol. 39, 1547-1554.

Southam G., and Saunders J. A. (2005) Geomicrobiology of ore deposits. Econ. Geol. 100, 1067-1084.

Sternbeck Joh, Sohlenius Gusta, and Hallberg R. O. (2000) Sedimentary trace elements as proxies to depositional changes induced by a Holocene fresh-brackish water transition. Aquat. Geochem. 6, 325-345.

Stuben Dori, Berner Zsol, Chandrasekharam D., and Karmakar Juli (2003) Arsenic enrichment in groundwater of West Bengal India: geochemical evidence for mobilization of As under reducing conditions. Appl. Geochem. 18, 1417-1434.

Sullivan K. A., and Aller R. C. (1996) Diagenetic cycling of arsenic in Amazon shelf sediments. Geochim. Cosmochim. Acta 60, 1465-1477.

Swartz C. H., Blute N. K., Badruzzman B., Ali A., Jay J., Besancon J., Islam S., Hemond H. F., and Harvey C. F. (2004) Mobility of arsenic in a Bangladesh aquifer: inferences from geochemical profiles, leaching data, and mineralogical characterization. Geochem. Cosmochim. Acta 68, 4539-4557.

Taggart, J. E. (2002) Analytical methods for chemical analysis of geologic and other materials, U.S. Geological Survey, U.S. Geol. Sur. Open-file Report 02-223. (Available at http:// pubs.usgs.gov/of/2002/ofr-02-0223/OFR-02-0223.pdf.

Tuttle M. L., Goldhaber M. B., and Williamson D. L. (1986) An analytical scheme for determining forms of sulfur in oil shales and associated rocks. Talanta 33, 953-961.

Umitsu M. (1993) Late quaternary sedimentary environments and landforms in the Ganges Delta. Sed. Geol. 83, 177-186.

van Geen A., Rose J., Thoral S., Garnier J. M., Zheng Y., and Bottero Y. Y. (2004) Decoupling of As and $\mathrm{Fe}$ release to Bangladesh ground water under reducing conditions. Part II:
Evidence from sediment incubations. Geochim. Cosmochim. Acta 68, 3475-3486.

van Geen A., Zheng Y., Cheng Z., Aziz A., Horneman A., Dhar R. K., Mailloux B., Stute M., Weinman B., Goodbred S., Seddique A. A., Hoque M. A., and Ahmed K. M. (2006) A transect of groundwater and sediment properties in Araihazar, Bangladesh: further evidence of decoupling between $\mathrm{As}$ and $\mathrm{Fe}$ mobilization. Chem. Geol. 228, 85-96.

van Geen A., Zheng Y., Versteeg R., Stute M., Horneman A., Dhar R. K., Steckler M., Gelman A., Small C., Ahsan H., Graziano J., Hussein I., and Ahmed K. M. (2003) Spatial variability of arsenic in 6000 tube wells in a $25 \mathrm{~km}^{2}$ area of Bangladesh. Water Res. Res. 39, 1140. doi:10.1029/ 2002WR00161.

Walker S. R., Jamieson H. E., Lanzirotti A., Andrade C. F., and Hall G. E. M. (2005) The speciation of arsenic in iron oxides in mine wastes from the Giant gold mine, N.W.T.: application of synchrotron micro-XRD. Can. Mineral 43, 1205-1244.

Wang Q., and Morse J. W. (1996) Pyrite formation under conditions approximating those in anoxic sediments; I. Pathway and morphology. Marine Chem. 52, 99-121.

Webb S. (2002) Sam's Interface for XAS Package (SixPACK) (available at http://www-ssrl.slac.stanford.edu/ swebb/ sixpack.htm).

Wilkin R. T., and Barnes H. L. (1997) Formation processes of framboidal pyrite. Geochim. Cosmochim. Acta 61, 323-339.

Wilkin R. T., and Ford R. G. (2002) Use of hydrochloric acid for determining solid-phase arsenic partitioning in sulfidic sediments. Environ. Sci. Technol. 36, 4921-4927.

Wilkin R. T., and Ford R. G. (2006) Arsenic solid-phase partitioning in reducing sediments of a contaminated wetland. Chem. Geol. 228, 156-174.

Wilkin R. T., Wallschlager D., and Ford R. G. (2003) Speciation of arsenic in sulfidic waters. Geochem. Trans. 4, 1-7.

Zheng Y., Stute M., van Geen A., Gavrieli I., Dhar R., Simpson H. J., Schlosser P., and Ahmed K. M. (2004) Redox control of arsenic mobilization in Bangladesh groundwater. Appl. Geochem. 19, 201-214. 